
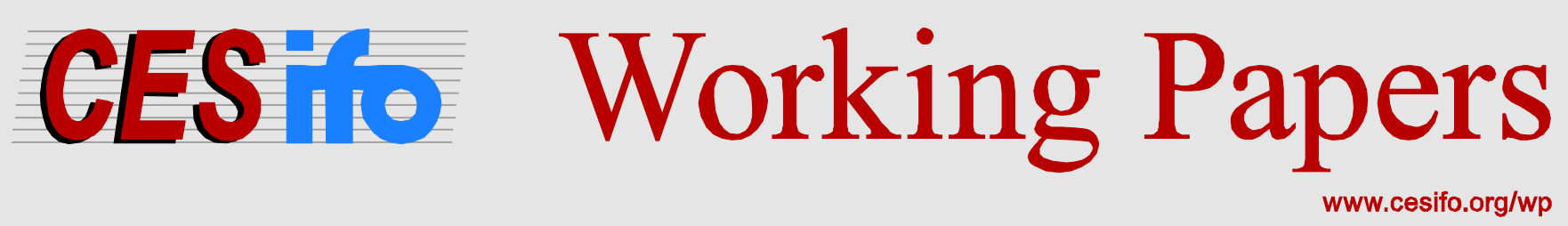

\title{
Does Pension Privatization Increase Economic Growth? Evidence from Latin America and Eastern Europe
}

\author{
Nikola Altiparmakov \\ Milan Nedeljkovic
}

CESIFO WORKING PAPER NO. 6074

CATEgORY 1: PUBLIC FinANCE

SEPTEMBER 2016

An electronic version of the paper may be downloaded

- from the SSRN website: Www.SSRN.com

- from the RePEc website: Www.RePEc.org

- from the CESifo website: www.CESifo-group.org/wp 


\title{
Does Pension Privatization Increase Economic Growth? Evidence from Latin America and Eastern Europe
}

\begin{abstract}
Analyses of pension funding effects on economic growth need to differentiate between 'carveout' pension privatization in Latin America and Eastern Europe and typical 'add-on' pension funding in Western Europe and North America. We find no evidence that pension privatization in Latin America and Eastern Europe was associated with higher economic growth. The result is robust across both continents and several alternative econometric specifications. Positive growth effects are particularly unlikely in countries resorting to debt-financed privatization. Furthermore, we note the lack of positive pension privatization effects on savings in Eastern Europe, with limited evidence of positive savings effects in Latin America. These findings suggest that cost-containment parametric reforms should be given priority over carve-out pension privatization when considering options for restoring financial sustainability of public Pay-As-You-Go systems.

JEL-Codes: J320, G280, H550, C230.
\end{abstract}

Keywords: pension funding, economic growth, national saving, emerging economies.

\author{
Nikola Altiparmakov \\ Fiscal Council of Serbia \\ Nemanjina 17 \\ Serbia - Belgrade 11000 \\ nalti@yahoo.com
}

\author{
Milan Nedeljkovic \\ National Bank of Serbia \& FEFA \\ Singidunum University \\ Kralja Petra 12 \\ Serbia-Belgrade 11000 \\ milan.nedeljkovic@nbs.rs
}

We are grateful to editor Michael Haliassos and three anonymous referees for comments that led to substantial improvements in the paper. We thank Milojko Arsic, Christian Saborowski, and participants at the 16th Banca d' Italia Fiscal Policy Workshop for other useful comments. The views expressed in the paper do not represent the official views of the Serbian Fiscal Council or the National Bank of Serbia. 


\section{Introduction}

Following the reform lead of Chile, many countries in Latin America and Eastern Europe have implemented 'carve-out' pension privatization over the last 25 years. This radical reform approach entails partial or complete termination of existing public Pay-As-YouGo pension schemes and the introduction of mandatory private individual pension accounts in their place, the so-called 'second pension pillar' in World Bank terminology. The carve-out approach is in contrast to the add-on approach typical in most advanced economies, where private funds develop in the form of (voluntary) supplementary funds on top of public pension schemes. At the time, the professional public was strongly divided regarding the feasibility of carve-out pension privatization. The World Bank (1994) favored pension privatization and argued that it would not only enable higher pensions for future beneficiaries (micro level) but would also accelerate economic growth and increase national saving at the macro level. The opponents challenged most of the expected reform benefits (Beattie and McGillivray 1995, Singh 1996, Barr 2000, Stiglitz and Orszag 2001).

One of crucial anticipated pension privatization benefits was an acceleration of economic growth that could generate additional resources to meet the future needs of an aging population. If positive effects on economic growth are absent, then it might be more feasible to instead consider parametric reforms that would financially stabilize existing PAYG systems amid demographic aging. At the time pension privatizations were implemented, a beneficial impact on economic growth was expected to arise through various channels. First and foremost, the contributions from privatized pension systems would be saved in individual accounts, thus increasing private savings. Increased savings should then lead to higher aggregate growth rates, provided that these funds were channeled into (productive) domestic investment. Second, privatized funds are used primarily in the local financial market, which could stimulate financial innovation at the local level (Holzmann 1997), reduce local financial market volatility (Thomas et al. 2014), promote foreign investor participation (Reece and Sam 2012), and stimulate overall capital market development (Catalan 2004). Financial development, in turn, has a well-discussed positive impact on economic growth (Demirguc-Kunt and Levine, 2001). Third, pension privatization could also have positive effects on firms' productivity and growth arising from improved corporate governance (Davis 2002, Davis and Hu 2008) and higher labor market efficiency (Disney et al. 2004).

This paper aims to expand the existing empirical literature on the cross-country effects of pension funding on economic growth, which has reported mixed results (see Thomas and Spataro 2016 for a recent survey). While Davis and Hu (2008) document a positive impact of pension asset size to growth in a sample of 38 developed and emerging economies, Zandberg and Spierdijk (2013) find limited impact in the long run and no effect in the short run in their sample of 54 countries. Their findings are in line with Samwick (2000), who finds limited evidence for higher trends in the rate of savings following pension system reforms in a broad sample of developed and emerging economies. 
All these studies differentiate between pension funding effects in developed and emerging economies, but they do not distinguish between add-on and carve-out approaches to pension funding. As the result of individual (welfare maximizing) decisions, add-on funding in the form of voluntary supplementary pension funds might be more likely to increase national savings than legally prescribed mandatory carve-out pension privatization. In the latter case, workers can decide to offset mandatory pension savings with reductions in other forms of voluntary saving, or the government might not implement the strict and long-lasting austerity measures required to preclude the emergence of transitional deficits and reductions in public saving (Barr 2000). Furthermore, Brown (1997) explains that in order to stimulate growth, any increased national savings need to be channeled into productive investments, which is more likely if the savings are the result of market interactions and welfare-maximizing decisions at the individual level rather than legally prescribed and mandatory. Finally, when assessing the financial development channel to economic growth, Orszag and Stiglitz (2001) highlight that capital market development depends on a myriad of factors, notably adequate institutional capacity and efficient regulation, which are also likely to differ since the add-on approach was typical in developed countries while the carve-out approach was prevalent in developing countries in Latin America and Eastern Europe. Thus, the add-on versus the carve-out approach to pension funding could have different effects on national savings and economic growth, and cross-sectional studies need to control for this possible source of heterogeneity.

In this paper we focus on investigating the growth and savings effects of carve-out pension privatizations in emerging economies and aim to expand the existing empirical literature, which reports mixed results in this area. Early studies (Holzmann 1997, Schmidt-Hebbel 1998) focus on the Chilean experience and find a positive relationship between pension reform and economic growth. Mesa-Lago (2002) examines the experience of Latin American countries in the early years of pension privatization and finds a lack of empirical support for the positive impact on national savings. The independent evaluation group of the World Bank (2006) concluded that "there is little evidence that privately funded pillars have succeeded in increasing national savings or in developing capital markets”. More recently, the World Bank noted the lack of studies in this area for Eastern Europe (Schwarz and Arias, 2014). We hope to fill this gap and to enrich existing analyses by examining the data from both Eastern Europe and Latin America.

To analyze the impact on growth and savings, we use unbalanced panel data covering 36 comparable countries in Eastern Europe, Central Asia, and Latin America over the 1990 to 2013 period. Nine countries in Latin America, ten in Eastern Europe, and one in Central Asia initiated pension privatization at some point in our sample, along with Chile, which privatized earlier. We employ several panel data estimators, controlling for static, dynamic, and time-varying effects of pension reform. The primary variable of interest pension reform - is defined as the share of an employee's wage that is allocated to private funds in the second pillar. This choice has some useful advantages, among which are that it allows capturing cross-sectional variation in the magnitude of pension privatization 
reforms and also implicitly controls for potentially endogenous factors that drive the level of GDP and the growth of pension assets.

Econometric analysis reveals that carve-out pension privatization failed to produce statistically significant positive impact on the growth rates of reforming countries compared to the general evolution of growth in non-reforming countries. The strength of the impact is even smaller for Eastern European countries. We also find a limited positive impact of pension reform on aggregate savings rates, which become statistically significant only after seven years following the reform, thus partially explaining the lack of evidence for the growth impact. Furthermore, we uncover an important conditional role of the private pension funds' portfolio allocation: the impact of pension reform on growth was systemically and often statistically significantly lower in countries where government bonds represent the dominant share (above 50\%) in the pension funds' portfolios.

This paper is organized as follows. Section 2 describes relevant methodological features and our dataset. Section 3 presents econometric analysis of pension privatization effects on economic growth and national saving. Relevant implications for policymaking are discussed in Section 4, while Section 5 concludes.

\section{Data and Methodology Description}

Pension privatization came in several flavors in Latin America. The Chilean prototype of completely terminating the existing public system and introducing private individual accounts in its place was followed in Bolivia (1997), Mexico (1997), El Salvador (1998), and the Dominican Republic (2003). Argentina (1994), Uruguay (1994), and Costa Rica (2000) opted for partial pension privatization whereby existing PAYG systems were reformed and partially scaled-down to make room for the second pension pillar. Peru (1993) and Columbia (1994) implemented parallel systems whereby workers were given an exclusive choice of participating either in a reformed public PAYG system or in second pillar individual accounts (Mesa-Lago, 2002). In Eastern Europe all countries opted for the partial pension privatization approach. Hungary initiated the process in 1998 and by 2008 ten Eastern European countries had introduced second pension pillars: Poland (1999), Latvia (2001), Bulgaria (2002), Croatia (2002), Estonia (2002), Lithuania (2004), Slovakia (2005), FYR Macedonia (2006), and Romania (2008). Finally, from Central Asia we include Kazakhstan, which completely privatized its pension system in 1998. Pension funding in all these countries was implemented in the carve-out fashion, with the exception of Estonia, which partially relied on the add-on approach (James 2005, Table 1). ${ }^{2}$

Our dataset includes annual data for 36 countries in Eastern Europe, Central Asia, and Latin America over the 1990 to 2013 period. Macro-level data for Eastern European and Central Asian countries starts in 1995 to avoid structural breaks and significant outliers

\footnotetext{
${ }^{2}$ In Estonia mandatory private pension funds' (MPFs) contributions total $6 \%$ of gross wages with $4 \%$ being diverted from the PAYG system and $2 \%$ representing additional contributions for workers participating in the second pillar.
} 
appearing in the early transitional period. The data for Latin American countries covers the entire sample. ${ }^{3}$ Table 1 shows 21 countries that have implemented pension reform, together with the year of privatization and contribution rates over time. Our identification of the 'treatment effect' thus relies on the data of 15 countries that did not pursue pension privatization and on the pre-reform data for countries that later privatized. The control group of 15 includes Albania, Armenia, Brazil, Czech Republic, Ecuador, Georgia, Guatemala, Honduras, Moldova, Nicaragua, Panama, Paraguay, Slovenia, Turkey, and Ukraine. $^{4}$

\section{[Insert Table 1]}

By using the second pillar contribution rate as the primary explanatory variable we are able to capture not only cross-country variation but also within-country variation since many countries progressively increased the second pillar contribution rate after the start of pension privatization, while several countries have also implemented partial or complete reform reversals in recent years. Alternatively, the second pillar annual contribution inflows (as a share of GDP) could be used as the primary explanatory variable. The advantage of this approach would be more precise measurement of relevant variation between different countries and across time, but the drawback is the need to deal with endogeneity issues inherent in its measurement. In addition, comprehensive and comparable data on this variable is not presently available for a broad number of countries in our sample, and this remains a possible avenue for future research.

Another important explanatory variable is the extent to which pension privatization is debt-financed, since the dominance of domestic government bonds in second pillar portfolios represents disguised-PAYG financing and not genuine pension funding (Altiparmakov 2015). In order to control for this heterogeneity we define a dummy variable that includes only countries where domestic government bonds account for less than half of second pillar portfolios: Chile, Columbia, Dominican Republic, and Peru in Latin America, and Bulgaria, Estonia, Latvia, Lithuania, and Slovakia in Eastern Europe. $^{5}$

Table 2 presents descriptive statistics for the main dependent variables of interest, growth rate of real GDP per capita and aggregate savings (as percentage of GDP), together with a few other relevant macro variables and control variables used in the empirical analysis. Summary statistics were obtained by first averaging the relevant variables within single countries, whereby for non-privatizing countries data was averaged over the entire time period and for privatizing countries time periods were split into before and after privatization. Then the overall mean values were obtained by using unweighted averaging

\footnotetext{
${ }^{3}$ The macro data is winsorized at $1 \%$ to eliminate the impact of extreme outliers; however, the results for our main variable of interest do not change with or without winsorizing.

${ }^{4}$ In Panama, individual accounts do exist for higher earners. However, this arrangement will not be considered as a second pension pillar for our purposes, as is the case in most other papers in this area. Armenia implemented a second pillar in 2014, but some of the legal provisions have been disputed in the constitutional court.

${ }^{5}$ This classification is based on Arenas De Mesa and Mesa-Lago (2006) for Latin American countries and national statistics at the end of 2012 for Eastern European economies.
} 
across countries. Data for Chile was not used since Chile privatized pensions prior to the period covered in our analysis. The sources for all variables are described in the Appendix.

\section{[Insert Table 2]}

While pension privatization was led by more developed Latin American countries such as Chile and Argentina, the most developed countries in Eastern Europe, Slovenia and the Czech Republic, opted not to privatize. ${ }^{6}$ We can nonetheless observe many common features across Latin America and Eastern Europe. Most importantly, there seems to be no obvious relationship between pension privatization and economic growth. GDP growth improved slightly after pension privatization in Eastern Europe and Central Asia, but GDP per capita growth deteriorated. The opposite pattern is observed in Latin America. With respect to the other variable of interest, the average savings rate increased in both Latin America and Eastern Europe after privatization. ${ }^{7}$ The same is true for investments, with a more tangible investment increase observed in Eastern Europe (likely due to high foreign investments from Western Europe during the transition process). Furthermore, we can observe reductions in inflation and improvements in political stability in privatizing countries in both Latin America and Eastern Europe. Nonetheless, it should be remembered that the period of pension privatization coincided with other large economic and societal changes - the period of great moderation in the case of Latin America and EU accession in the case of Eastern Europe. We thus turn to formal econometric analysis to isolate the effects of pension privatization on growth and savings.

\section{Pension privatization effects on economic growth and national savings}

\subsection{Framework}

In this section, we move to the econometric analysis. In particular, we estimate different variants of the following reduced-form model:

$$
y_{i t}=\alpha_{i}+\mu_{t}+\beta P_{i t}+X_{i t-1}^{t} \phi+\varepsilon_{i t}
$$

The dependent variable $y_{i t}$ is the growth rate of real GDP per capita (Section 3.2) and gross domestic savings as percentage of GDP (Section 3.3) in country $i$ at time $t$. We include country fixed effects and year fixed effects to control for time-invariant drivers of growth/savings and global trends, respectively. The vector $X_{i t}$ includes time-varying covariates, typically included in the growth (Barro and Sala-i-Martin, 2004) and savings literature (see survey in Cusolito and Nedeljkovic, 2013). The primary variable of interest is pension reform, $P_{i, t}$, which we define in two ways. First, we define $P_{i, t}$ to equal zero or the second pillar contribution rate, as discussed previously. Second, to allow for the

\footnotetext{
${ }^{6}$ After prolonged political debate, the Czech Republic did implement a second pillar in 2013, only to terminate it less than a year after it was introduced. Since a marginal number of workers (voluntarily) entered the second pillar in 2013, we will be treating the Czech Republic as a non-privatizing country in this article.

${ }^{7}$ Domestic saving for non-privatized countries in Eastern Europe is somewhat downward biased due to tangibly negative savings in many years in Albania, Armenia, and Moldova.
} 
possibility of the time-varying impact of the reform and minimize the associated misspecification bias, we follow Laporte and Windmeijer (2005) and alternatively define $P_{i, t}$ as a vector of dummy ('pulse') variables for three non-overlapping periods ${ }^{8} \cdot \mathrm{P}_{\mathrm{it}}{ }^{0-2}$ equals zero for all years apart from the year of second pillar introduction and the two subsequent years; $\mathrm{P}_{\mathrm{it}}{ }^{3-6}$ is non-zero over three to six years following pension privatization, and $\mathrm{P}_{\mathrm{it}}{ }^{7+}$ covers the period starting from seven years after the reform. ${ }^{9}$ Finally, our particular interest in identifying differences between Eastern Europe and Latin America and between countries resorting to debt-financing versus countries implementing adequate austerity policies leads us to include two interaction terms with the pension reform variable: interaction with a dummy that takes the value 1 for Eastern European countries and interaction with a dummy that takes the value 1 for countries in which domestic government bonds represent a small share (bellow 50\%) of pension fund assets.

In empirical analysis we need to make several econometric choices. First, we estimate specification (1) in three temporal settings: static fixed effect regression, dynamic fixed effect regression, and fixed effect regression with non-overlapping five-year averages (classical empirical growth model).

The static fixed effect regression serves as the benchmark. We then assess the impact of the persistence in the dependent variable by estimating a dynamic specification. Nickell (1981) showed the inconsistency of the standard fixed effect estimator in the presence of the lagged dependent variable. Since the cross-sectional dimension is relatively small to efficiently employ common Arellano-Bond and Blundell-Bond estimators (Arellano and Bond 1991; Blundell and Bond 1998), we follow Zandberg and Spierdijk (2013) and use the bias-corrected least square dummy variable (LSDV) estimator (Bun and Kiviet 2003; Bruno 2005). We use higher-order approximation of the bias, of order $O\left(N^{-1} T^{1}\right)$, and initialize the procedure with a standard Blundell-Bond estimator. Finally, to alternatively assess the long-run impact of the pension reforms, we also estimate fixed effect regression with non-overlapping five-year averages, noting that the last observation is based on a three-year (2011-13) average. ${ }^{10}$

Second, the inclusion of country fixed effects controls for factors such as social norms, colonial and legal origin, and geography, which may influence both economic and social development. In this way some of the endogeneity concerns are mitigated, as the consistency of the fixed effect estimator allows for correlation with the persistent component of the error term and requires the pension reform variable to be uncorrelated only with innovations in the omitted time-varying factors and shocks to the dependent variable that enter the error term (Wooldridge, 2010). In addition, year fixed effects account for common global trends in growth rates (Section 3.2) and savings (Section 3.3).

\footnotetext{
${ }^{8}$ The same methodology has been applied in growth studies in other contexts: see, inter alia, Papaioannou and Siourounis (2007) and Smith (2015).

${ }^{9}$ Since Argentina and Hungary terminated the second pillar close to the end of our sample, we also check the results when the $\mathrm{P}_{\mathrm{it}}{ }^{7+}$ is set to zero from the first year of the reversal and find no significant impact on the results.

${ }^{10}$ We also estimate the model with overlapping five-year averages data, with no impact on the main results.
} 
Despite using the fixed effects and the standard set of covariates, the dependent variable and the pension variable may still be driven by the omitted time and country-varying factors. Our definition of the pension variable relative to the more commonly used ratio of pension assets to GDP is targeted towards mitigating these concerns. Nevertheless, it is still possible that the decision to privatize may be affected by additional omitted growth and savings factors. In further robustness checks we allow for this possibility and estimate the model parameters using the two-stage procedure; however, the results remain unaffected. Finally, a necessary condition for establishing causality is the randomness of the pension reform variable. The non-selectivity assumption is difficult to attain as pension reform is typically pre-announced and is the result of a multi-year process. Our second (vector) definition of the pension reform variable aims to control the anticipation bias by including the additional term $\mathrm{P}_{\mathrm{it}}{ }^{-2 t o-1}$ for the two years that precede the reform. The main results, however, remain unaffected.

Third, our fixed effect difference-in-difference model suffers from a downward bias in the standard errors arising from positive residual serial correlation (Bertrand et al. 2004). To control for this in the static model we use robust standard errors, allowing for countrylevel clustered autocorrelation and heteroscedasticity. In dynamic and overlapping specification we bootstrap the standard errors, using 500 bootstrap repetitions.

\subsection{Results of growth regressions}

This section presents the results of the growth regressions. We start by presenting the results of our benchmark specification, first assuming a time-invariant impact of the reform (Table 3) and then tracing the time-varying effects (Table 4). Last, we compare the evidence using alternative temporal frameworks (Table 5).

Table 3, columns (1)-(3), report results from a simple univariate regression estimated via OLS, including country and year effects respectively. Estimated coefficients for pension reform in pooled OLS and country fixed effect regression are positive but statistically insignificant. The fit of the models, however, is rather poor. Inclusion of year effects improves the fit, but the coefficient for pension reform remains statistically insignificant. In columns (4)-(5) we add interaction terms. None of the coefficients for the pension reform variables is statistically significant. Nevertheless, we see the first signal that the growth performance of Eastern Europe countries that privatized pensions was additionally negative. Moreover, privatizing countries with lower shares of government bonds in pension funds' portfolios appear to have a stronger growth association. Columns (6)-(8) report conditional results when the set of growth determinants is included. We include the standard growth determinants in the literature (Barro and Sala-i-Martin 2004): i) the real GDP per capita level (lagged two periods) as a proxy for convergence effects; ii) lagged real investment to real GDP ratio as a proxy for the effect of the savings rate in the neoclassical growth model; iii) lagged government consumption to GDP ratio and lagged inflation as a proxy for adverse effects of government actions and macroeconomic uncertainty on private decisions; iv) male upper-level schooling (Barro and Lee 2010) and life expectancy at birth as proxies for the quality of human capital; v) polity index as a proxy for the growth impact of democracy (Acemogly et al. 2008); and vi) lagged trade 
openness and lagged terms-of-trade changes as a proxy for the impact of trade policies and commodity shocks. ${ }^{11}$ With the exception of human capital proxies and the real GDP per capita level, all control variables enter with a lag to control for potential reverse causality. The results when each covariate is included separately do not qualitatively or quantitatively differ and are not reported for paper parsimony. The results yet again confirm the absence of a statistically significant impact of the reform on growth rates relative to the case of no privatization. On the other hand, typical growth covariates have the expected signs and the estimated coefficients for most of them are statistically significant. The only exception is the Barro-Lee (2010) measure of male secondary school attainment, which enters with a negative sign, though it is not statistically significant. $^{12}$

\section{[Insert Table 3]}

Table 4 repeats the exercise, now allowing for the time-varying effects of pension privatization. Indeed, the estimated coefficients fluctuate over the reform horizon with different signs and statistical significance. Columns (1)-(3) report the results when pension privatization is defined as a vector of pulse variables, together with interaction terms. While all coefficients for the base variables are statistically insignificant, the interaction term for Eastern European countries from seven years after the reform is negative and statistically significant. This seems to suggest a negative link between pension reform and growth performance in European countries, though, despite including year dummies, a part of the effect could be related to the impact of the global financial crisis, which overlaps with the post-privatization period in most of the European countries. When the covariates are included in the regressions, columns (4)-(6), the signs and the magnitudes of the coefficients for the control variables remain similar to earlier results in Table (3). On the other hand, the signs and statistical significance of the pension reform variable change in certain directions. In particular, the association becomes negative and weakly statistically significant three years after privatization in the case of Eastern European countries (the p-value for the sum of the coefficients is 0.019) and for countries in which government bonds represent a dominant share of second pillar assets. As mentioned earlier, negative results for Eastern Europe could be driven by the coincidence of the post-privatization period and the global financial crisis, which impacted the European region more severely than Latin America. It could also indicate a systematic difference between pension privatization performance in Latin America and Eastern Europe. On the other hand, results in columns (4)-(6) could indicate that the dominance of government bonds in second pillar portfolios, which is a well-known feature of suboptimal pension privatization design, could have detrimental effects on economic growth. Both of these issues will be explored further in Section 4. The last three columns, (7)-(9), control for the anticipation bias by including the $\mathrm{P}_{\mathrm{it}}{ }^{-2 \mathrm{to}-1}$ variable and its interaction terms, with no significant impact on the earlier results.

\footnotetext{
${ }^{11}$ We adjust the trade openness series to control for the impact of the country size, proxied by the logs of population and area.

${ }^{12}$ The finding can be related to the interpolation procedure used to construct the variable (which is available only at five-year frequency) and the fact that the human capital effects tend to materialize in the long run. Indeed, the variable becomes statistically significant and positive with five-year averages data.
} 
Table 5 presents the results of alternative temporal settings: dynamic fixed effect regression, columns (1)-(3), and traditional long-run growth (non-overlapping five-year averages) regressions, columns (4-6). ${ }^{13}$ Following Bond et al. (2010), dynamic specification is estimated as the autoregressive distributed lag model (ARDL), which includes the first lag of the dependent variable (growth), the first lag of the change in explanatory variables and the lag of the levels of each variable. The results from the dynamic analysis confirm the lack of a statistically significant impact of pension privatization on growth and are mostly in line with previous results. ${ }^{14}$

The long-run growth regressions are estimated over the 1996-2000, 2001-05, 2006-10 and 2011-13 periods. The pension variable enters with a value before the beginning of the period (1995, 2000, 2005, and 2010). To control for endogeneity, macro covariates enter as five-year averages over the previous period, while human capital, democracy, and initial income enter with a five-period lag. We also include three period dummies to control for country invariant events. Even though the time series dimension is small (both for constructing the averages and for the number of averages), it is still useful to compare the findings to earlier results. Our 'long-run' estimates indicate no evidence of positive effects of carve-out pension funding on long-run growth. On the other hand, Zandberg and Spierdijk (2013), working with another sample of 54 advanced and developing countries over the 2001-10 period, found limited evidence for positive effects of pension funding on growth. However, Zandberg and Spierdijk (2013) do not control for carve-out versus add-on approaches to pension funding, and they note that positive correlation is driven by several outliers - huge percentage increases in pension assets in countries with low-base pension accumulations. Since our approach precludes the possibility of such outliers, we can conclude that our results are very much in line with the results of Zandberg and Spierdijk (2013) that exclude the aforementioned outliers.

\section{[Insert Table 5]}

We perform several other robustness checks, which are reported in Tables A1-A3 in the Appendix. First, to control for the potential endogeneity of the pension privatization variable, we estimate control function instrumental variable regressions. In particular, given the censored character of the pension privatization variable, we estimate first stage Tobit regressions and use generalized residuals from the first stage model as an additional explanatory variable in the second-stage regressions. Following Reece and Sam (2012), we use the expected increase in the pensioner-to-worker ratio (which we proxy with the 20-year difference in the old-age dependency ratio, Lane and Milessi-Ferretti 2012) and

\footnotetext{
${ }^{13}$ We also estimated benchmark and time-varying specifications with alternative measures of GDP per capita (in constant PPP dollars, in constant local currency) with no impact on the results.

${ }^{14}$ We also perform Im et al's (2003) unit root tests, which reject the null hypothesis of non-stationarity of the growth series at all conventional significance levels. On the other hand, the test suggests nonstationarity of the log-level series. The ARDL specification offers a useful framework that does not violate the time series properties of the data, while it avoids estimating panel cointegration models, given the modest time-series dimension of the sample.
} 
the number of regional peer countries that have enacted privatization as the first stage instruments. ${ }^{15}$ Both instruments are statistically significant and enter the first stage regressions with the expected sign. More importantly, the second stage estimates of pension privatization impact do not deviate from earlier findings. Second, the inclusion of country fixed effects (while controlling for the time invariant drivers of economic development) may also drive the results to the extent that the within-variation in the pension privatization variable may not be sufficiently large to allow capturing the growth effects of privatization. Analogously, time fixed effects may capture the positive growth effects of pension privatizations if the reforms were implemented in the same year across a number of countries. To mitigate these concerns we repeat our regressions without fixed effects and the results remain broadly the same ${ }^{16}$. Third, another related concern is whether the analysis suffers from the small sample problem - the lack of power of the estimators to detect any significant association between the pension variable and our dependent variables. To evaluate the extent of the small sample problem we perform a small Monte Carlo experiment where we use actual data on the pension reform variable and generate 5,000 artificial datasets of the same size as our actual dataset, allowing for fixed effects, exogenous covariates, and within-cluster autocorrelation and heteroscedasticity. The results show that the parameters are tightly estimated and that the t-test of the statistical significance of the pension variable is not oversized. The power of the t-test increases with the magnitude of the coefficient on the pension reform variable, as expected, but even for assumed values of the parameters that imply small economic effects (0.05), the power of the test is above $50 \%$ and very quickly reaches $95 \%$. Overall, Monte Carlo results indicate that small sample issues are not likely to drive our findings.

In sum, the econometric results suggest limited association between carve-out pension privatization and growth performance over the first 20 or less years after the reform. The link is negative and statistically significant for a period of 3 to 6 years following the reform for Eastern European countries. Moreover, it is also negative and statistically significant over the medium term in countries with a higher share of (domestic) government bonds in pension funds' portfolios.

\subsection{Results of savings regressions}

This section analyzes whether a part of the explanation for the lack of positive evidence on growth can be rationalized from the relation between carve-out privatization and aggregate savings. ${ }^{17}$ Tables 6-8 repeat the structure of the growth analysis, now with a modified set of covariates that reflects the common determinants of savings discussed in the literature. We include: i) the lagged level of GDP per capita and the lagged government consumption to GDP ratio; ii) credit to the private sector (as share of GDP) as a proxy for financial deepening and relaxation of borrowing constraints: iii)

\footnotetext{
${ }^{15}$ The lagged growth rate of GDP as an alternative instrument is not statistically significant in the firststage regressions.

${ }^{16}$ The only difference to our previous results is that the coefficient on $\mathrm{P}_{\mathrm{it}}{ }^{0-2}$ is positive and statistically significant when fixed effects are excluded.

${ }^{17}$ We use gross domestic savings as the dependent variable of interest; the results do not change if gross national savings are used instead.
} 
dependency ratio as a proxy for the impact of demographic change; iv) unemployment rate as a proxy for higher macroeconomic uncertainty and consequently higher precautionary savings; v) terms-of-trade changes as a proxy for the impact of temporary versus permanent increases in income in commodity-exporting countries; and vi) inflation rate as a proxy for the potential depreciation of savings returns. Factors related to real interest rates, social security programs, and labor market policies are not included due to the lack of consistent data of sufficient cross-sectional dimension. All control variables outside demographics enter with a lag to control for potential reverse causality.

Table 6, columns (1)-(5), show that the magnitude of the coefficients for pension reform decreases with the inclusion of country and year fixed effects. Estimated coefficients for the pension reform variable shrink further when the control variables are included. Although none of the coefficients is statistically significant, we see that the effect of pension reform in Eastern European countries could potentially be negative. With the exception of the dependency ratio, all covariates have the expected signs and the majority are statistically significant.

\section{[Insert Table 6]}

Table 7, columns (1)-(6), document a significant time variation in the direction and the strength of the effect. Privatization has a positive impact on gross domestic savings with the horizon of seven years and the estimated coefficient is weakly statistically significant with and without covariates. Column (5) shows that Latin American countries drive the observed pattern. The estimated coefficient in levels is positive and statistically significant, while the interaction term for Eastern European countries is negative and the sum of the two terms is not statistically significant (p-value equal to 0.61). Moreover, in Eastern European reforming countries, gross savings also fall in the short run as both the interaction term and the sum of the coefficients for $\mathrm{P}_{\mathrm{it}}{ }^{0-2}$ are negative and statistically significant (p-value equal to 0.057). The anticipation bias (columns (7)-(9)) again does not influence the main results, although we see that in all privatization countries savings fall in the two years preceding the reform, relative to earlier periods.

\section{[Insert Table 7]}

Table 8 repeats the analysis using dynamic fixed effect regression, columns (1)-(3), and long-run OLS regression with non-overlapping five-year averages, columns (4-6). Dynamic specification is again estimated as the autoregressive distributed lag model, which includes the first lag of the change in the dependent (savings) and explanatory variables and the first lag of the levels of each variable. The long-run regressions are estimated over the 1996-2000, 2001-05, 2006-10 and 2011-13 periods. The pension variable, dependency ratio, and gross income enter with a value before the beginning of the period (1995, 2000, 2005, and 2010), while macro covariates enter as five-year averages over the previous period. As before, we include three period dummies to control for country-invariant events. The pension variables remain statistically insignificant in all specifications. Income effects and terms-of-trade changes appear to be the dominant explanatory variables of savings behavior over the sample. 
[Insert Table 8]

In addition, we perform several other robustness checks, which are reported in Tables A4-A5 in the Appendix. As in the previous section, the main results do not change if we use two-stage estimates or if we exclude country and time fixed effects.

\section{Implications for policymaking}

There are two basic approaches to dealing with aging-induced financing problems of earnings-related public pension schemes. The first approach, followed in traditional Bismarckian countries such as Germany and Austria, is to implement cost-containment parametric reforms to restore financial sustainability of the PAYG system and to foster the (voluntary) development of private funds in an add-on manner to supplement more modest public benefits in coming decades. In the second approach, instead of supplementing, private pension funds partially or completely substitute publicly provided pension benefits. Over the last 25 years many countries in Latin America and Eastern Europe opted for this second, more radical, reform approach, hoping to achieve significant economic benefits. Existing literature describes that, contrary to initial expectations, pension privatization failed to deliver many of the anticipated benefits. ${ }^{18}$ In this paper we analyzed the salient issue of pension privatization effects on economic growth.

Our analysis shows no evidence that pension privatization was associated with accelerated economic growth. These findings are robust across several different specifications, and applicable to privatizing countries in both Latin America and Eastern Europe. To confirm this result we further analyze the main anticipated channel of growth acceleration via increased savings. The evidence on savings effects seems to be mixed. While there is some evidence that pension privatization was associated with higher domestic saving in Latin America, there is no such indication for Eastern Europe. While this evidence should be considered as preliminary and requiring more elaborate further research, it could point to systematic differences in pension privatization effects in Latin America and Eastern Europe.

While all Eastern European countries opted for partial pension privatization (to reduce transition costs), complete privatization was prevalent in Latin America. Transition costs were severely underestimated and neglected during preparatory reform stages on both continents (Mesa-Lago, 2002; Azra, 2008; Drahokoupil and Domonkos, 2012). Groundbreaking privatization in Chile was accompanied with strict and long-lasting austerity measures that produced a surplus of $8.5 \%$ of GDP in the non-pension part of the public sector over the 1981-2004 period (Arenas De Mesa and Mesa-Lago, 2006).

\footnotetext{
18 Arenas de Mesa and Mesa-Lago (2006) show that worker coverage, instead of increasing, actually decreased in all ten Latin American countries after privatization. Azra (2008) shows that second pillar returns net of management fees were lower than the PAYG internal rate of return in Argentina. Altiparmakov $(2011,2015)$ shows that the same was true in most Eastern European countries, even before the emergence of the global financial crisis.
} 
However, Impavido and Rocha (2006) note that other reforming countries were mostly unsuccessful in implementing adequate austerity measures and have thus resorted to debtfinanced transitions and large issues of government bonds, which ended up in the portfolios of second pillar pension funds. These circular transactions do not constitute genuine pension funding but are basically a disguised-PAYG financing mechanism that increases public debt (Altiparmakov 2015). To cope with unresolved transition costs, financing countries can either implement adequate austerity measures or consider reform reversals. ${ }^{19}$ However, reversing a complete pension privatization is arguably more challenging and less likely than reversing a partial one. Latin American countries were thus more likely to implement additional austerity measures that would increase public (and aggregate) savings, which possibly would help explain the different savings effects in Latin America compared to Eastern Europe. ${ }^{20}$

Unresolved transition-cost financing issues manifest themselves through the emergence of disguised-PAYG financing, where second pillar funds invest most of their assets in government bonds that were issued to finance transition costs in the first place. This feature, common to both Latin America and Eastern European reformers, indicates an inefficient pension system design that both increases public debt and reduces beneficiaries' rates of return compared to traditional (non-financial defined contribution) PAYG financing. Our econometric analysis indicates that disguised PAYG financing could also have detrimental effects on growth and savings. The results of savings regressions are in line with Schwarz and Arias's (2014) suggestions that debt-financed transition is unlikely to increase savings. Regarding possible detrimental growth effects, we note the possibility of deteriorating investor confidence, since explicit public debt is treated less favorably than the implicit pension debt (Cueves et al, 2008). Overall, we can conclude that the lack of political support for the strict and long-lasting austerity measures required to preclude the emergence of disguised-PAYG financing severely undermines the feasibility of carve-out pension privatization.

Davis and $\mathrm{Hu}$ (2008) note that a key issue in pension reform is whether shifting from PAYG to funding is largely a matter of reallocation of the burden of aging (with the risk of a generation paying twice), or whether funding improves economic performance sufficiently to generate at least some of the additional resources required to meet the needs of an aging population. The absence of growth-enhancing evidence we have documented undermines pension privatization feasibility and highlights the importance of cost-containment parametric reforms that can restore the financial sustainability of existing PAYG systems; for example, by introducing non-financial defined contribution (NDC) systems. This option seems especially appealing for reforming countries with pronounced presence of disguised-PAYG financing.

\footnotetext{
${ }^{19}$ We use 'reform reversals' in this article, since this term has become widespread after being introduced by the World Bank. We make use of this term without imputing any implicit value judgment.

${ }^{20}$ In support of this hypothesis we note several instances of reform reversal in Eastern Europe, such as that in Hungary, Poland, Slovakia, and Latvia. Some authors argue that these reversals were driven by unaccommodating EU fiscal rules (Casey 2014; Schwarz and Arias 2014). Without debating the cause of reform reversals, we note that Argentina, one of three Latin American countries that also opted for partial privatization, also implemented reform reversals in 2001 (partially) and in 2008 (completely).
} 


\section{Concluding remarks}

When analyzing the effects of pension funding on growth and savings, it is necessary to differentiate between carve-out pension privatization in Latin America and Eastern Europe and the add-on pension funding that is typical of North America and Western Europe. We found no evidence that the carve-out pension privatization in Latin America and Eastern Europe is associated with higher economic growth, compared to similar countries that did not privatize. This finding is robust across both continents and across several different econometric specifications. Since privatization plans highlighted increased savings as the major anticipated channel for growth acceleration, we further analyze pension privatization effects on saving.

We find no evidence that privatization in Eastern Europe was associated with higher domestic saving, while there is limited evidence of higher saving in Latin America. This could potentially indicate systematic differences between the effects of partial privatization in Eastern Europe and of the complete pension privatization that was prevalent in Latin America. More elaborate future research is needed to establish firmer evidence on differing effects in Latin America versus Eastern Europe. To this end, future research efforts could establish a comprehensive database on second pillar annual contribution inflows, which would allow for more refined econometric analyses.

We further note the importance of adequate and long-lasting austerity measures to accompany carve-out pension privatization: otherwise, reforming countries will resort to large issues of government bonds, which will likely end up in second pillar portfolios. This results in disguised PAYG financing and an inefficient pension system that is particularly unlikely to stimulate economic growth or aggregate savings.

A lack of positive growth effects undermines the feasibility of carve-out pension privatization compared to traditional cost-containment parametric PAYG reform. Thus, when considering options for restoring the financial sustainability of earnings-related public pension schemes amid demographic aging, countries are advised to pay more attention to the experience of the gradual reforms implemented in traditional Bismarckian countries such as Germany than to the radical pension privatization pioneered by Chile. 


\section{REFERENCES}

Acemoglu, D., Johnson, S., Robinson, J.A. and Yared, P. (2008) Income and Democracy. American Economic Review, 98 (3): 808-842.

Altiparmakov, N. (2015) A call for more elaborate and transparent pension data to inform policy-making: A critical examination of World Bank data for Eastern Europe. International Social Security Review, 68 (2): 1-25.

Altiparmakov, N. (2011) A macro-financial analysis of pension system reforms in emerging Europe: The performance of IRAs and policy lessons for Serbia. International Social Security Review, 64 (2): 23-44.

Arrelano, M. and Bond, S. (1991) Some tests of specification for panel data: Monte-Carlo evidence and an application to employment equations. Review of Economic Studies, 58: 277-297.

Arenas De Mesa, A. and Mesa-Lago, C. (2006) The Structural Pension Reform in Chile: Effects, Comparations with other Latin American Reforms and Lessons. Oxford Journal of Economic Policy, 22:1:149-167.

Barr, N. (2000) Reforming Pensions: Myths, Truths and Policy Choices. IMF Working Paper No. WP/00/139

Barro, R., Sala-I-Martin, X. (2004): Economic Growth. Cambridge, MA: MIT Press.

Barro, R.and Lee,J. (2010) A New Data Set of Educational Attainment in the World, 1950-2010. Journal of Development Economics, 104:184-198

Beattie, R. and W. McGillivray. (1995) A Risky Strategy: Reflections on the World Bank Report Averting the old age crisis. International Social Security Review, 48(3):5-22.

Bertrand, M., Duflo, E., Mullainathan, S. (2004) How much should we trust differences in-differences estimates? Quarterly Journal of Economics 119 (1): 249-275.

Blundell, R. and Bond, S. (1998) Initial conditions and moment restrictions in dynamic panel data models. Journal of Econometrics, 87(1): 115-143.

Bond, S., Leblebicioglu, A. and Schiantarelli, F. (2010) Capital accumulation and growth: a new look at the empirical evidence. Journal of Applied Econometrics 25: 1073-1099.

Brown, R. L. (1997) In Defense of Pay-as-You-Go (Paygo) Financing of Social Security. North American Actuarial Journal, 1(1), 1-20

Bruno, G. (2005) Approximating the bias of the LSDV estimator for dynamic unbalanced panel data models. Economics Letters, 87: 361-366.

Bun, M. and Kiviet, J. (2003) On the diminishing returns of higher-order terms in asymptotic expansions of bias. Economics Letters, 79: 145-152.

Casey, B. (2014) From pension funds to piggy banks: (Perverse) consequences of the Stability and Growth Pact since the crisis. International Social Security Review, 67: 27-48.

Catalan, M. (2004). Pension funds and corporate governance in developing countries: What do we know and what do we need to know? Journal of Pension Economics and Finance, 2(3): 197-232.

Cusolito, A. P., and Nedeljkovic, M. (2013). Toolkit for the analysis of current account imbalances. International Trade Department, World Bank

Cuevas, A., Gonzales, M., Davide, L. and López-Marmolejo, A. (2008) Pension privatization and country risk. IMF working paper No. WP/08/195. 
Davis, E. (2002) Institutional investors, corporate governance and the performance of the corporate sector. Economic Systems, 26: 203-229.

Davis, E. and Hu, Y.-W. (2008) Does funding of pensions stimulate economic growth? Journal of Pension Economics and Finance, 7: 221-249.

Disney, R., Boeri, T. and Jappelli, T. (2004) Are contributions to public pension programmes a tax on employment?. Economic Policy, 19(39): 269-311.

Drahokoupil, J. and S. Domonkos. (2012). Averting the funding-gap crisis: East European pension reforms since 2008. Global Social Policy, 12(3): 283-299.

Holzmann, R. (1997). Pension reform, financial market development, and economic growth: Preliminary evidence from Chile. IMF Staff Papers, 44(2):149-178.

Impavido, G. and Rocha, R. (2006) Competition and Performance in Hungarian Second Pillar. World Bank Policy Research Working Paper 3876

James, E. (2005) Reforming Social Security: Lessons from Thirty Countries. NCPA Policy Report No. 277

Lane, P. and G. Milesi-Ferretti, (2012). External adjustment and the global crisis. Journal of International Economics, 88(2): 252-265.

Laporte, A., Windmeijer, F. (2005) Estimation of panel data models with binary indicators when treatment effects are not constant over time. Economics Letters 88 (3): 389-396

Orszag, P., \& Stiglitz, J. E. (2001). Rethinking pension reform: Ten myths about social security systems. In R. Holman, \& J. E. Stiglitz (eds.), New ideas about old age security: Toward sustainable pension systems in the twenty-first century (pp. 17-56). World Bank, Washington, DC.

Papaioannou, E., Siourounis, G. (2008) Democratization and growth. Economic Journal 118 (532): 1520-1551.

Reece, C. and Sam, A. (2012) Impact of pension privatization on foreign direct investment. World Development 40 (2): 291-302.

Schwartz, A.M. and Arias, O.S. (2014) The Inverting pyramid: Pension systems facing demographic challenges in Europe and Central Asia, World Bank, Washington, DC.

Singh, A. (1996). Pension reform, the stock market, capital formation and economic growth: A critical commentary on the World Bank's proposals. International Social Security Review, 49(3): 21-43.

Smith, B. (2015) The resource curse exorcised: Evidence from a panel of countries. Journal of Development Economics 116: 57-73.

Thomas, A., Spataro, L. (2016) The Effects of Pension Funds on Markets Performance: A Review. Journal of Economic Surveys 30: 1-33.

Thomas, A., Spataro, L., Mathew, N. (2014) Pension funds and stock market volatility: An empirical analysis of OECD countries. Journal of Financial Stability 11: 92-103.

Zandberg, E and Spierdijk, L: (2013). Funding of pensions and economic growth: are they really related?. Journal of Pension Economics and Finance, 12: 151-167.

Wooldridge, J. M. (2010). Econometric analysis of cross section and panel data. Cambridge, MA: MIT Press

World Bank (1994). Averting the old-age crisis: Policies to protect the old and promote growth. Oxford University Press 
World Bank (2006) Pension reform and the development of pension systems - An Evaluation of the World Bank assistance. Independent Evaluation Group. Washington, USA 


\section{Data Appendix:}

\begin{tabular}{|c|c|c|}
\hline Variable & Definition & Source \\
\hline Pension reform & $\begin{array}{l}\text { Legally prescribed second pillar contribution } \\
\text { rate, as percentage of earnings }\end{array}$ & $\begin{array}{l}\text { FIAP data for Latin America, } \\
\text { authors’ compilation of official } \\
\text { data for Eastern Europe }\end{array}$ \\
\hline Eastern European & Dummy for Eastern European countries & - \\
\hline Low Government bond & $\begin{array}{l}\text { Dummy variable for countries with } \\
\text { government bonds accounting less than half } \\
\text { of second pillar assets }\end{array}$ & $\begin{array}{l}\text { Arenas de Mesa and Mesa-Lago } \\
\text { (2006) for Latin America, authors } \\
\text { compilation of official end-2012 } \\
\text { statistics for Eastern Europe }\end{array}$ \\
\hline Real GDP per capita & In constant 2011 PPP USD & WDI \\
\hline Gross Domestic Savings & In percentage of GDP & WDI \\
\hline Gross Investment & In percentage of GDP & WDI \\
\hline $\begin{array}{l}\text { General government } \\
\text { consumption }\end{array}$ & In percentage of GDP & WDI \\
\hline Inflation & 1+(GDP deflator/100) & WDI \\
\hline Male upper level schooling & $\begin{array}{c}\text { Years of Secondary Schooling of male } \\
\text { population }\end{array}$ & Barro and Lee (2010) \\
\hline Life expectancy at birth & Years & WDI \\
\hline Polity index & Signed variable & The Center for Systemic Peace \\
\hline Terms of trade & Percentage change & WEO \\
\hline Trade openness & $\begin{array}{l}\text { Sum of exports and imports over GDP, } \\
\text { corrected for country size }\end{array}$ & WDI \\
\hline Credit to private sector & In percentage of GDP & WDI \\
\hline Unemployment rate & In percentage of total working force & WDI \\
\hline Dependency ratio & Share of population below 15 and above 65 & WDI \\
\hline Ageing speed & $\begin{array}{l}\text { The } 20 \text { year difference in the old age } \\
\text { dependency ratio }\end{array}$ & UN and WDI \\
\hline
\end{tabular}


Table 1 - Second pillar contribution rates, \% of earnings:

\begin{tabular}{|c|cccccc|}
\hline & $\mathbf{1 9 9 0}$ & $\mathbf{1 9 9 5}$ & $\mathbf{2 0 0 0}$ & $\mathbf{2 0 0 5}$ & $\mathbf{2 0 1 0}$ & $\mathbf{2 0 1 3}$ \\
\hline Argentina (1994) & 0 & 7.7 & 7.7 & 4.4 & 0 & 0 \\
Bolivia (1997) & 0 & 0 & 10.0 & 10.0 & 10.5 & 10.5 \\
Bulgaria (2002) & 0 & 0 & 0 & 4.0 & 5.0 & 5.0 \\
Chile (1981) & 10.0 & 10.0 & 10.0 & 10.0 & 10.0 & 10.0 \\
Columbia (1994) & 0 & 10.0 & 10.0 & 10.5 & 11.5 & 11.5 \\
Costa Rica (2000) & 0 & 0 & 4.3 & 4.3 & 4.3 & 4.3 \\
Croatia (2002) & 0 & 0 & 0 & 5.0 & 5.0 & 5.0 \\
Dominican Rep (2003) & 0 & 0 & 0 & 6.0 & 8.0 & 8.0 \\
El Salvador (1998) & 0 & 0 & 10.0 & 10.0 & 10.3 & 10.8 \\
Estonia (2002) & 0 & 0 & 0 & 6.0 & 2.0 & 6.0 \\
Hungary (1998) & 0 & 0 & 6.0 & 8.0 & 8.0 & 0 \\
Kazakhstan(1998) & 0 & 0 & 10.0 & 10.0 & 10.0 & 10.0 \\
Latvia (2001) & 0 & 0 & 0 & 2.0 & 2.0 & 4.0 \\
Lithuania (2004) & 0 & 0 & 0 & 3.5 & 2.0 & 2.5 \\
Macedonia (2006) & 0 & 0 & 0 & 0 & 7.4 & 7.4 \\
Mexico (1997) & 0 & 0 & 4.9 & 5.0 & 7.7 & 7.8 \\
Peru (1993) & 0 & 8.0 & 8.0 & 8.0 & 10.0 & 10.0 \\
Poland (1999) & 0 & 0 & 7.3 & 7.3 & 7.3 & 2.8 \\
Romania (2008) & 0 & 0 & 0 & 0 & 2.5 & 4.0 \\
Slovakia (2005) & 0 & 0 & 0 & 9.0 & 9.0 & 4.0 \\
Uruguay (1996) & 0 & 0 & 12.3 & 12.0 & 12.0 & 12.0 \\
\hline
\end{tabular}

Notes: Data sources are explained in Data Appendix. 
Table 2 - Summary description of the data:

\begin{tabular}{|c|c|c|c|}
\hline \multirow[b]{2}{*}{$\begin{array}{l}19 \text { Eastern Europe and Central Asia } \\
\text { countries, 1995-2013 }\end{array}$} & \multirow[b]{2}{*}{$\begin{array}{l}\text { Non-privatized } \\
\text { countries mean }\end{array}$} & \multicolumn{2}{|c|}{ Privatized countries mean } \\
\hline & & $\begin{array}{c}\text { Before } \\
\text { privatization }\end{array}$ & $\begin{array}{c}\text { After } \\
\text { privatization }\end{array}$ \\
\hline GDP growth, in \% & 3.97 & 3.25 & 3.45 \\
\hline GDPpc growth, in \% & 4.10 & 4.07 & 3.86 \\
\hline Govt Consumption (\% GDP) & 15.89 & 16.62 & 17.01 \\
\hline Imports (\% of GDP) & 51.41 & 40.30 & 57.21 \\
\hline Exports (\% of GDP) & 38.58 & 35.64 & 52.31 \\
\hline Inflation (GDP deflator), in \% & 1.17 & 1.33 & 1.05 \\
\hline Domestic savings (\% of GDP) & 12.31 & 15.89 & 21.00 \\
\hline Investment (\% of GDP) & 23.70 & 19.55 & 24.35 \\
\hline Polity Index & 7.26 & 6.48 & 7.90 \\
\hline Dependency ratio, in \% & 48.22 & 49.37 & 45.92 \\
\hline GDPpc in USD & 5571 & 4753 & 7984 \\
\hline Unemployment rate, in \% & 11.13 & 14.36 & 12.50 \\
\hline
\end{tabular}

\begin{tabular}{|c|c|c|c|}
\hline \multirow[b]{2}{*}{16 Latin America countries, 1990-2013 } & \multirow{2}{*}{$\begin{array}{l}\text { Non-privatized } \\
\text { countries mean }\end{array}$} & \multicolumn{2}{|c|}{ Privatized countries mean } \\
\hline & & $\begin{array}{c}\text { Before } \\
\text { privatization }\end{array}$ & $\begin{array}{c}\text { After } \\
\text { privatization }\end{array}$ \\
\hline GDP growth, in \% & 3.80 & 3.82 & 3.69 \\
\hline GDPpc growth, in \% & 1.83 & 2.19 & 2.49 \\
\hline Govt Consumption (\% GDP) & 12.24 & 9.83 & 12.49 \\
\hline Imports (\% of GDP) & 42.89 & 24.80 & 29.35 \\
\hline Exports (\% of GDP) & 37.88 & 21.98 & 26.02 \\
\hline Inflation (GDP deflator), in \% & 2.16 & 4.17 & 1.08 \\
\hline Domestic savings (\% of GDP) & 16.84 & 14.66 & 16.33 \\
\hline Investment (\% of GDP) & 20.05 & 16.57 & 18.88 \\
\hline Polity Index & 7.44 & 7.20 & 7.99 \\
\hline Dependency ratio, in \% & 70.37 & 69.60 & 60.70 \\
\hline GDPpc in USD & 2621 & 3359 & 4276 \\
\hline Unemployment rate, in \% & 6.17 & 8.08 & 8.58 \\
\hline
\end{tabular}

Notes: Data sources are explained in Data Appendix. 
Table 3: Growth regressions: Fixed effect static estimation:

\begin{tabular}{|c|c|c|c|c|c|c|c|c|}
\hline Variable & 1 & 2 & 3 & 4 & 5 & 6 & 7 & 8 \\
\hline Pension reform & $\begin{array}{c}0.0191 \\
(0.0536)\end{array}$ & $\begin{array}{c}0.0353 \\
(0.0637)\end{array}$ & $\begin{array}{l}-0.0201 \\
(0.0742)\end{array}$ & $\begin{array}{l}-0.0184 \\
(0.0856)\end{array}$ & $\begin{array}{l}-0.0508 \\
(0.0855)\end{array}$ & $\begin{array}{l}0.00378 \\
(0.0549)\end{array}$ & $\begin{array}{c}-0.0233 \\
(0.0651)\end{array}$ & $\begin{array}{l}-0.0603 \\
(0.0650)\end{array}$ \\
\hline Pension ref.*E. Europe & & & & $\begin{array}{c}-0.00427 \\
(0.158)\end{array}$ & & & $\begin{array}{l}0.0819 \\
(0.128)\end{array}$ & \\
\hline Pension ref.*Low Gov. bond & & & & & $\begin{array}{l}0.0976 \\
(0.140)\end{array}$ & & & $\begin{array}{l}0.214 * \\
(0.125)\end{array}$ \\
\hline Per capita GDP & & & & & & $\begin{array}{c}-12.07 * * * \\
(1.797)\end{array}$ & $\begin{array}{c}-12.17 * * * \\
(1.768)\end{array}$ & $\begin{array}{c}-12.20 * * * \\
(1.812)\end{array}$ \\
\hline Investment & & & & & & $\begin{array}{c}0.137 * * * \\
(0.0423)\end{array}$ & $\begin{array}{c}0.137 * * * \\
(0.0415)\end{array}$ & $\begin{array}{c}0.134 * * * \\
(0.0419)\end{array}$ \\
\hline Government consumption. & & & & & & $\begin{array}{c}-0.277 * * * \\
(0.0889)\end{array}$ & $\begin{array}{c}-0.269 * * * \\
(0.0888)\end{array}$ & $\begin{array}{c}-0.290 * * * \\
(0.0882)\end{array}$ \\
\hline Inflation & & & & & & $\begin{array}{c}-2.264 * * \\
(0.910)\end{array}$ & $\begin{array}{c}-2.220 * * \\
(0.936)\end{array}$ & $\begin{array}{c}-2.318 * * \\
(0.924)\end{array}$ \\
\hline Male upp. lev. schooling & & & & & & $\begin{array}{l}-0.849 \\
(0.931)\end{array}$ & $\begin{array}{l}-0.945 \\
(0.943)\end{array}$ & $\begin{array}{l}-1.064 \\
(1.030)\end{array}$ \\
\hline Life expectancy at birth & & & & & & $\begin{array}{l}-0.520^{*} \\
(0.282)\end{array}$ & $\begin{array}{l}-0.518 * \\
(0.284)\end{array}$ & $\begin{array}{l}-0.511 * \\
(0.285)\end{array}$ \\
\hline Polity index & & & & & & $\begin{array}{c}0.0236 * * * \\
(0.00809)\end{array}$ & $\begin{array}{c}0.0233 * * * \\
(0.00844)\end{array}$ & $\begin{array}{c}0.0255^{* * *} \\
(0.00875)\end{array}$ \\
\hline Terms of trade & & & & & & $\begin{array}{l}0.0320 * \\
(0.0164)\end{array}$ & $\begin{array}{l}0.0319 * \\
(0.0163)\end{array}$ & $\begin{array}{l}0.0300 * \\
(0.0175)\end{array}$ \\
\hline Trade openness & & & & & & $\begin{array}{c}0.0108 \\
(0.0125)\end{array}$ & $\begin{array}{l}0.00963 \\
(0.0128)\end{array}$ & $\begin{array}{c}0.0117 \\
(0.0125)\end{array}$ \\
\hline $\begin{array}{l}\text { Observations } \\
\text { Cross sections }\end{array}$ & 764 & 764 & 764 & 764 & 764 & 636 & 636 & 636 \\
\hline $\mathrm{R} 2$ & 0.000 & 0.001 & 0.302 & 0.302 & 0.303 & 0.464 & 0.465 & 0.469 \\
\hline Adjusted R2 & -0.001 & -0.001 & 0.279 & 0.278 & 0.279 & 0.437 & 0.437 & 0.440 \\
\hline Time/Country FE & No/No & No/Yes & Yes/Yes & Yes/Yes & Yes/Yes & Yes/Yes & Yes/Yes & Yes/Yes \\
\hline
\end{tabular}

Notes: The dependent variable is the annual growth rate of real GDP per capita multiplied by 100. The numbers in parentheses are robust clustered standard errors. *, ** and *** denote significance at $10 \%, 5 \%$ and $1 \%$. Pension reform variable is defined equal zero or the second pillar contribution rate. Eastern European is zeroone dummy for Eastern European countries. Low government bond is zero-one dummy for countries and periods in which less than $50 \%$ of total pension fund assets is invested in local government bonds. Per capita GDP is logged and twice lagged. Investment and Government consumption are defined in share of GDP. Inflation is based on GDP deflator. Terms of trade are defined in percentage change. Trade openness is corrected for the country size. All macro variables are lagged once. 
Table 4: Growth regressions: Time varying estimation:

\begin{tabular}{|c|c|c|c|c|c|c|c|c|c|}
\hline Variable & 1 & 2 & 3 & 4 & 5 & 6 & 7 & 8 & 9 \\
\hline Pension (0-2) & $\begin{array}{c}0.0684 \\
(0.0483)\end{array}$ & $\begin{array}{c}0.0711 \\
(0.0590)\end{array}$ & $\begin{array}{c}0.0384 \\
(0.0577)\end{array}$ & $\begin{array}{c}0.0410 \\
(0.0466)\end{array}$ & $\begin{array}{c}0.0545 \\
(0.0447)\end{array}$ & $\begin{array}{l}-0.00434 \\
(0.0734)\end{array}$ & $\begin{array}{c}0.0352 \\
(0.0498)\end{array}$ & $\begin{array}{c}0.0443 \\
(0.0470)\end{array}$ & $\begin{array}{l}-0.0123 \\
(0.0870)\end{array}$ \\
\hline Pension (3-6) & $\begin{array}{l}-0.0808 \\
(0.0830)\end{array}$ & $\begin{array}{l}-0.0800 \\
(0.0764)\end{array}$ & $\begin{array}{c}-0.142 \\
(0.113)\end{array}$ & $\begin{array}{c}-0.0602 \\
(0.0671)\end{array}$ & $\begin{array}{l}-0.0555 \\
(0.0690)\end{array}$ & $\begin{array}{c}-0.171 * * \\
(0.0813)\end{array}$ & $\begin{array}{l}-0.0690 \\
(0.0685)\end{array}$ & $\begin{array}{l}-0.0680 \\
(0.0709)\end{array}$ & $\begin{array}{c}-0.180 * * \\
(0.0860)\end{array}$ \\
\hline Pension (7+) & $\begin{array}{l}-0.0222 \\
(0.0773)\end{array}$ & $\begin{array}{c}0.0715 \\
(0.0777)\end{array}$ & $\begin{array}{l}-0.0525 \\
(0.0802)\end{array}$ & $\begin{array}{l}-0.0760 \\
(0.0678)\end{array}$ & $\begin{array}{c}-0.0569 \\
(0.0761)\end{array}$ & $\begin{array}{l}-0.165^{*} \\
(0.0863)\end{array}$ & $\begin{array}{l}-0.0831 \\
(0.0675)\end{array}$ & $\begin{array}{l}-0.0620 \\
(0.0740)\end{array}$ & $\begin{array}{l}-0.175^{*} \\
(0.0863)\end{array}$ \\
\hline Pens.(0-2)*E. Europe & & $\begin{array}{c}-0.0577 \\
(0.106)\end{array}$ & & & $\begin{array}{c}-0.0639 \\
(0.142)\end{array}$ & & & $\begin{array}{l}-0.0527 \\
(0.152)\end{array}$ & \\
\hline Pens.(3-6)*E. Europe & & $\begin{array}{l}-0.165 \\
(0.118)\end{array}$ & & & $\begin{array}{l}-0.187 * * \\
(0.0847)\end{array}$ & & & $\begin{array}{c}-0.183 * * \\
(0.0811)\end{array}$ & \\
\hline Pens.(7+)*E. Europe & & $\begin{array}{c}-0.304 * * * \\
(0.110)\end{array}$ & & & $\begin{array}{c}-0.0186 \\
(0.142)\end{array}$ & & & $\begin{array}{c}-0.0125 \\
(0.140)\end{array}$ & \\
\hline Pens. $(0-2) *$ Low Gov. bond & & & $\begin{array}{c}0.0536 \\
(0.0886)\end{array}$ & & & $\begin{array}{c}0.0665 \\
(0.0942)\end{array}$ & & & $\begin{array}{l}0.0710 \\
(0.104)\end{array}$ \\
\hline Pens.(3-6)*Low Gov. bond & & & $\begin{array}{c}0.125 \\
(0.114)\end{array}$ & & & $\begin{array}{l}0.229 * * \\
(0.0931)\end{array}$ & & & $\begin{array}{l}0.221 * * \\
(0.0905)\end{array}$ \\
\hline Pens.(7+)*Low Gov. bond & & & $\begin{array}{l}0.0665 \\
(0.121)\end{array}$ & & & $\begin{array}{c}0.217 \\
(0.138)\end{array}$ & & & $\begin{array}{c}0.223 \\
(0.133)\end{array}$ \\
\hline Per capita GDP & & & & $\begin{array}{c}-12.05^{* * *} \\
(1.740)\end{array}$ & $\begin{array}{c}-11.68 * * * \\
(1.806)\end{array}$ & $\begin{array}{c}-12.19 * * * \\
(1.675)\end{array}$ & $\begin{array}{c}-12.03 * * * \\
(1.724)\end{array}$ & $\begin{array}{c}-11.69 * * * \\
(1.846)\end{array}$ & $\begin{array}{c}-12.15^{* * *} \\
(1.652)\end{array}$ \\
\hline Investment & & & & $\begin{array}{c}0.138 * * * \\
(0.0440)\end{array}$ & $\begin{array}{c}0.131 * * * \\
(0.0462)\end{array}$ & $\begin{array}{c}0.130 * * * \\
(0.0411)\end{array}$ & $\begin{array}{c}0.135 * * * \\
(0.0445)\end{array}$ & $\begin{array}{l}0.125 * * \\
(0.0465)\end{array}$ & $\begin{array}{c}0.126 * * * \\
(0.0415)\end{array}$ \\
\hline Government consumption & & & & $\begin{array}{c}-0.264^{* * *} \\
(0.0891)\end{array}$ & $\begin{array}{c}-0.267^{* * *} \\
(0.0904)\end{array}$ & $\begin{array}{c}-0.288^{* * *} \\
(0.0850)\end{array}$ & $\begin{array}{c}-0.267 * * * \\
(0.0895)\end{array}$ & $\begin{array}{c}-0.278 * * * \\
(0.0894)\end{array}$ & $\begin{array}{c}-0.292^{* * *} \\
(0.0859)\end{array}$ \\
\hline Inflation & & & & $\begin{array}{c}-2.247 * * \\
(0.926)\end{array}$ & $\begin{array}{c}-2.303^{* *} \\
(0.942)\end{array}$ & $\begin{array}{c}-2.257^{* *} \\
(0.900)\end{array}$ & $\begin{array}{c}-2.205^{* *} \\
(0.929)\end{array}$ & $\begin{array}{c}-2.246^{* *} \\
(0.941)\end{array}$ & $\begin{array}{c}-2.215^{* *} \\
(0.899)\end{array}$ \\
\hline Male upp. lev. schooling & & & & $\begin{array}{c}-0.673 \\
(0.963)\end{array}$ & $\begin{array}{c}-0.427 \\
(0.963)\end{array}$ & $\begin{array}{c}-1.144 \\
(1.140)\end{array}$ & $\begin{array}{l}-0.697 \\
(0.953)\end{array}$ & $\begin{array}{c}-0.412 \\
(0.960)\end{array}$ & $\begin{array}{l}-1.187 \\
(1.142)\end{array}$ \\
\hline Life expectancy at birth & & & & $\begin{array}{c}-0.559 * \\
(0.278)\end{array}$ & $\begin{array}{c}-0.574^{*} \\
(0.282)\end{array}$ & $\begin{array}{c}-0.684^{* *} \\
(0.284)\end{array}$ & $\begin{array}{c}-0.566 * * \\
(0.274)\end{array}$ & $\begin{array}{c}-0.588^{* *} \\
(0.275)\end{array}$ & $\begin{array}{c}-0.700 * * \\
(0.283)\end{array}$ \\
\hline Polity index & & & & $\begin{array}{l}0.0225^{* *} \\
(0.00833)\end{array}$ & $\begin{array}{c}0.0215^{* * *} \\
(0.00745)\end{array}$ & $\begin{array}{l}0.0244 * * \\
(0.00916)\end{array}$ & $\begin{array}{c}0.0231 * * * \\
(0.00825)\end{array}$ & $\begin{array}{c}0.0219 * * * \\
(0.00763)\end{array}$ & $\begin{array}{c}0.0250 * * * \\
(0.00895)\end{array}$ \\
\hline Terms of trade & & & & $\begin{array}{l}0.0332 * \\
(0.0166)\end{array}$ & $\begin{array}{c}0.0342 * * \\
(0.0167)\end{array}$ & $\begin{array}{l}0.0308^{*} \\
(0.0181)\end{array}$ & $\begin{array}{l}0.0329 * \\
(0.0167)\end{array}$ & $\begin{array}{l}0.0326 * \\
(0.0170)\end{array}$ & $\begin{array}{c}0.0303 \\
(0.0182)\end{array}$ \\
\hline Trade openness & & & & $\begin{array}{c}0.0130 \\
(0.0125)\end{array}$ & $\begin{array}{c}0.0178 \\
(0.0130)\end{array}$ & $\begin{array}{c}0.0177 \\
(0.0118)\end{array}$ & $\begin{array}{c}0.0123 \\
(0.0125)\end{array}$ & $\begin{array}{c}0.0178 \\
(0.0129)\end{array}$ & $\begin{array}{c}0.0170 \\
(0.0118)\end{array}$ \\
\hline
\end{tabular}


Pens.(-2to-1)*Low Gov. bond

\section{Observations}

Cross sections

R2

Adjusted R2

Time/Country FE

76

764
36
0.307

0.283

Yes/Yes

764
36
0.323
0.297

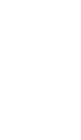

36

0.311

0.283

Yes/Yes

GDP per capita multiplied by 100. The numbers in parentheses are robust clustered standard errors. *, ** and *** denote significance at $10 \%, 5 \%$ and $1 \%$. Pension reform variables are defined as $\mathrm{P}(0-2)$ equals zero for all years apart from the year of the change in the contribution rate and the subsequent two years; $\mathrm{P}(3-6)$ is non-zero over three to six years following the change and $\mathrm{P}(7 \mathrm{on})$ covers period starting from seven years following the reform. Eastern European is zero-one dummy for Eastern European countries. Low government bond is zero-one dummy for countries and periods in which less than 50\% of total pension fund assets is invested in local government bonds. Per capita GDP is logged and twice lagged. Investment and Government consumption are defined in share of GDP. Inflation is based on GDP deflator. Terms of trade are defined in percentage change. Trade openness is corrected for the country size. All macro variables are lagged once. P(-2to-1) is non-zero for two years that precede the reform. 
Table 5: Growth regressions: Dynamic and long-run regressions:

\begin{tabular}{|c|c|c|c|c|c|c|}
\hline Variable & 1 & 2 & 3 & 4 & 5 & 6 \\
\hline Pension reform & $\begin{array}{l}-0.0214 \\
(0.0519)\end{array}$ & $\begin{array}{l}-0.0335 \\
(0.0619)\end{array}$ & $\begin{array}{c}-0.0743 \\
(0.0606)\end{array}$ & $\begin{array}{l}-0.0612 \\
(0.0458)\end{array}$ & $\begin{array}{l}-0.0747 \\
(0.0492)\end{array}$ & $\begin{array}{l}-0.0719 \\
(0.0629)\end{array}$ \\
\hline Pens. ref.*E. Europe & & $\begin{array}{c}0.0380 \\
(0.103)\end{array}$ & & & $\begin{array}{c}0.0690 \\
(0.131)\end{array}$ & \\
\hline Pens. ref.*Low Gov. bond & & & $\begin{array}{l}0.183^{*} \\
(0.100)\end{array}$ & & & $\begin{array}{c}0.0264 \\
(0.0963)\end{array}$ \\
\hline Per capita GDP (2y) & $\begin{array}{c}-6.671 * * * \\
(1.356)\end{array}$ & $\begin{array}{c}-6.701 * * * \\
(1.355)\end{array}$ & $\begin{array}{c}-6.950 * * * \\
(1.354)\end{array}$ & & & \\
\hline Lagged pc GDP growth & $\begin{array}{c}0.207 * * * \\
(0.0381)\end{array}$ & $\begin{array}{c}0.207^{* * *} \\
(0.0382)\end{array}$ & $\begin{array}{c}0.199 * * * \\
(0.0380)\end{array}$ & & & \\
\hline Per capita GDP (5y) & & & & $\begin{array}{c}-1.493 * * \\
(0.606)\end{array}$ & $\begin{array}{c}-1.610 * * \\
(0.667)\end{array}$ & $\begin{array}{c}-1.462 * * \\
(0.674)\end{array}$ \\
\hline Investment & $\begin{array}{c}0.188 * * * \\
(0.0457)\end{array}$ & $\begin{array}{c}0.188 * * * \\
(0.0459)\end{array}$ & $\begin{array}{c}0.189 * * * \\
(0.0456)\end{array}$ & $\begin{array}{c}-0.134^{* *} \\
(0.0521)\end{array}$ & $\begin{array}{c}-0.136 * * \\
(0.0546)\end{array}$ & $\begin{array}{c}-0.138 * * \\
(0.0581)\end{array}$ \\
\hline Government consumption & $\begin{array}{c}-0.215^{* *} \\
(0.0842)\end{array}$ & $\begin{array}{c}-0.210 * * \\
(0.0860)\end{array}$ & $\begin{array}{c}-0.231 * * * \\
(0.0837)\end{array}$ & $\begin{array}{c}0.0277 \\
(0.0623)\end{array}$ & $\begin{array}{c}0.0260 \\
(0.0619)\end{array}$ & $\begin{array}{c}0.0275 \\
(0.0690)\end{array}$ \\
\hline Inflation & $\begin{array}{c}-2.272 * * * \\
(0.799)\end{array}$ & $\begin{array}{c}-2.252 * * * \\
(0.804)\end{array}$ & $\begin{array}{c}-2.371 * * * \\
(0.804)\end{array}$ & $\begin{array}{c}0.0470 \\
(0.549)\end{array}$ & $\begin{array}{c}0.0479 \\
(0.515)\end{array}$ & $\begin{array}{c}0.0466 \\
(0.635)\end{array}$ \\
\hline Male upp. lev. schooling & $\begin{array}{c}0.344 \\
(0.571)\end{array}$ & $\begin{array}{c}0.309 \\
(0.578)\end{array}$ & $\begin{array}{c}0.0634^{* *} \\
(0.0276)\end{array}$ & $\begin{array}{c}1.219 * * * \\
(0.332)\end{array}$ & $\begin{array}{c}1.187^{* * *} \\
(0.336)\end{array}$ & $\begin{array}{c}1.216^{* * *} \\
(0.348)\end{array}$ \\
\hline Life expectancy at birth & $\begin{array}{c}0.179 \\
(0.155)\end{array}$ & $\begin{array}{c}0.192 \\
(0.158)\end{array}$ & $\begin{array}{r}-0.00939 \\
(0.0266)\end{array}$ & $\begin{array}{c}0.103 \\
(0.0917)\end{array}$ & $\begin{array}{c}0.120 \\
(0.104)\end{array}$ & $\begin{array}{c}0.0971 \\
(0.0956)\end{array}$ \\
\hline Polity index & $\begin{array}{c}-0.0129 \\
(0.0265)\end{array}$ & $\begin{array}{c}-0.0137 \\
(0.0265)\end{array}$ & $\begin{array}{c}0.189 \\
(0.155)\end{array}$ & $\begin{array}{c}0.0120 \\
(0.0923)\end{array}$ & $\begin{array}{c}0.0120 \\
(0.0907)\end{array}$ & $\begin{array}{c}0.0131 \\
(0.0989)\end{array}$ \\
\hline Terms of trade & $\begin{array}{c}0.0659 * * \\
(0.0277)\end{array}$ & $\begin{array}{c}0.0658 * * \\
(0.0277)\end{array}$ & $\begin{array}{c}0.198 \\
(0.580)\end{array}$ & $\begin{array}{c}0.0498 \\
(0.0591)\end{array}$ & $\begin{array}{c}0.0577 \\
(0.0634)\end{array}$ & $\begin{array}{c}0.0462 \\
(0.0632)\end{array}$ \\
\hline Trade openness & $\begin{array}{l}0.00400 \\
(0.0108)\end{array}$ & $\begin{array}{l}0.00328 \\
(0.0108)\end{array}$ & $\begin{array}{l}0.00452 \\
(0.0108)\end{array}$ & $\begin{array}{l}-0.00273 \\
(0.00741)\end{array}$ & $\begin{array}{l}-0.00389 \\
(0.00854)\end{array}$ & $\begin{array}{l}-0.00233 \\
(0.00790)\end{array}$ \\
\hline Observations & 634 & 634 & 634 & 115 & 115 & 115 \\
\hline Cross sections & 33 & 33 & 33 & 33 & 33 & 33 \\
\hline $\mathrm{R} 2$ & & & & 0.383 & 0.386 & 0.384 \\
\hline Adjusted R2 & & & & 0.303 & 0.300 & 0.297 \\
\hline Time/Country FE & Yes/Yes & Yes/Yes & Yes/Yes & Yes/No & Yes/No & Yes/No \\
\hline
\end{tabular}

Notes: The dependent variable in columns (1-3) is the annual growth rate of real GDP per capita multiplied by 100 . The dependent variable in columns (4-6) is the average annual growth rate of real GDP per capita multiplied by 100 over five year windows. The numbers in parentheses are bootstrap standard errors. ${ }^{*}, * *$ and $* * *$ denote significance at $10 \%, 5 \%$ and $1 \%$. Pension reform variable is defined equal zero or the second pillar contribution rate. Eastern European is zero-one dummy for Eastern European countries. Low government bond is zero-one dummy for countries and periods in which less than $50 \%$ of total pension fund assets is invested in local government bonds. The pension reform variables in columns (4-6) are lagged 5 years (the start of the window). The macro explanatory variables in columns (1-3) are lagged once (per capita GDP twice). The macro explanatory variables in columns (4-6) are lagged five year averages. Per capita GDP, human capital variables and Polity index in columns (4-6) enter with 5 year lag. Coefficients for the changes in the covariates in columns (1-3) are not reported to save space. 
Table 6: Savings regressions: Fixed effect static estimation:

\begin{tabular}{|c|c|c|c|c|c|c|c|c|}
\hline Variable & 1 & 2 & 3 & 4 & 5 & 6 & 7 & 8 \\
\hline Pension reform & $\begin{array}{c}0.419 \\
(0.298)\end{array}$ & $\begin{array}{c}0.228 \\
(0.138)\end{array}$ & $\begin{array}{c}0.130 \\
(0.170)\end{array}$ & $\begin{array}{l}0.0822 \\
(0.215)\end{array}$ & $\begin{array}{c}0.141 \\
(0.211)\end{array}$ & $\begin{array}{c}-0.00632 \\
(0.138)\end{array}$ & $\begin{array}{c}0.157 \\
(0.209)\end{array}$ & $\begin{array}{l}0.0255 \\
(0.188)\end{array}$ \\
\hline Pens. ref.*E. Europe & & & & $\begin{array}{c}0.125 \\
(0.303)\end{array}$ & & & $\begin{array}{l}-0.409 \\
(0.286)\end{array}$ & \\
\hline Pens. ref.*Low Gov. bond & & & & & $\begin{array}{r}-0.0365 \\
(0.293)\end{array}$ & & & $\begin{array}{c}-0.108 \\
(0.328)\end{array}$ \\
\hline Per capita GDP & & & & & & $\begin{array}{c}13.05 * * * \\
(4.433)\end{array}$ & $\begin{array}{c}13.51 * * * \\
(4.206)\end{array}$ & $\begin{array}{c}13.21 * * * \\
(4.454)\end{array}$ \\
\hline Credit to private sector & & & & & & $\begin{array}{c}-0.0705^{*} \\
(0.0375)\end{array}$ & $\begin{array}{c}-0.0692 * \\
(0.0369)\end{array}$ & $\begin{array}{c}-0.0720 * \\
(0.0383)\end{array}$ \\
\hline Government consumption & & & & & & $\begin{array}{c}-0.844 * * * \\
(0.170)\end{array}$ & $\begin{array}{c}-0.890 * * * \\
(0.175)\end{array}$ & $\begin{array}{c}-0.841^{* * *} \\
(0.175)\end{array}$ \\
\hline Dependency ratio & & & & & & $\begin{array}{c}0.195 \\
(0.143)\end{array}$ & $\begin{array}{c}0.198 \\
(0.141)\end{array}$ & $\begin{array}{c}0.195 \\
(0.146)\end{array}$ \\
\hline Inflation & & & & & & $\begin{array}{c}-0.653 \\
(1.470)\end{array}$ & $\begin{array}{c}-0.882 \\
(1.429)\end{array}$ & $\begin{array}{c}-0.646 \\
(1.506)\end{array}$ \\
\hline Terms of trade & & & & & & $\begin{array}{c}0.0692 * * \\
(0.0339)\end{array}$ & $\begin{array}{c}0.0690 * * \\
(0.0322)\end{array}$ & $\begin{array}{c}0.0699 * \\
(0.0349)\end{array}$ \\
\hline Unemployment rate & & & & & & $\begin{array}{c}0.190 \\
(0.195)\end{array}$ & $\begin{array}{c}0.171 \\
(0.192)\end{array}$ & $\begin{array}{c}0.182 \\
(0.204)\end{array}$ \\
\hline Observations & 758 & 758 & 758 & 758 & 758 & 700 & 700 & 700 \\
\hline Cross sections & 36 & 36 & 36 & 36 & 36 & 36 & 36 & 36 \\
\hline $\mathrm{R} 2$ & 0.032 & 0.016 & 0.054 & 0.055 & 0.054 & 0.291 & 0.300 & 0.291 \\
\hline Adjusted R2 & 0.031 & 0.015 & 0.023 & 0.023 & 0.022 & 0.260 & 0.268 & 0.260 \\
\hline Time/Country FE & No/No & No/Yes & Yes/Yes & Yes/Yes & Yes/Yes & Yes/Yes & Yes/Yes & Yes/Yes \\
\hline
\end{tabular}

Notes: The dependent variable is the share of gross domestic savings in GDP. The numbers in parentheses are robus clustered standard errors. *, ** and $* * *$ denote significance at $10 \%, 5 \%$ and $1 \%$. Pension reform variable is defined equal zero or the second pillar contribution rate. Eastern European is zero-one dummy for Eastern European countries. Low government bond is zero-one dummy for countries and periods in which less than $50 \%$ of total pension fund assets is invested in local government bonds. Per capita GDP is logged. Credit to private sector and Government consumption are defined in share of GDP. Inflation is based on GDP deflator. Terms of trade are defined in percentage change. All macro variables are lagged once. 
Table 7: Savings regressions: Time varying estimation:

\begin{tabular}{|c|c|c|c|c|c|c|c|c|c|}
\hline Variable & 1 & 2 & 3 & 4 & 5 & 6 & 7 & 8 & 9 \\
\hline Pension (0-2) & $\begin{array}{l}0.0134 \\
(0.101)\end{array}$ & $\begin{array}{c}0.0589 \\
(0.0977)\end{array}$ & $\begin{array}{c}-0.0330 \\
(0.172)\end{array}$ & $\begin{array}{c}-0.0379 \\
(0.0857)\end{array}$ & $\begin{array}{c}0.0321 \\
(0.0903)\end{array}$ & $\begin{array}{r}-0.0793 \\
(0.156)\end{array}$ & $\begin{array}{c}-0.0603 \\
(0.0973)\end{array}$ & $\begin{array}{c}0.00708 \\
(0.102)\end{array}$ & $\begin{array}{l}-0.103 \\
(0.187)\end{array}$ \\
\hline Pension (3-6) & $\begin{array}{l}0.0463 \\
(0.130)\end{array}$ & $\begin{array}{l}0.0545 \\
(0.131)\end{array}$ & $\begin{array}{r}-0.0245 \\
(0.189)\end{array}$ & $\begin{array}{c}0.00513 \\
(0.127)\end{array}$ & $\begin{array}{c}-0.00480 \\
(0.122)\end{array}$ & $\begin{array}{l}-0.0356 \\
(0.183)\end{array}$ & $\begin{array}{r}-0.0300 \\
(0.126)\end{array}$ & $\begin{array}{l}-0.0486 \\
(0.118)\end{array}$ & $\begin{array}{r}-0.0621 \\
(0.193)\end{array}$ \\
\hline Pension $(7+)$ & $\begin{array}{l}0.445^{*} \\
(0.262)\end{array}$ & $\begin{array}{c}0.386 \\
(0.297)\end{array}$ & $\begin{array}{c}0.419 \\
(0.332)\end{array}$ & $\begin{array}{c}0.414^{*} \\
(0.209)\end{array}$ & $\begin{array}{c}0.497^{*} \\
(0.269)\end{array}$ & $\begin{array}{c}0.399 \\
(0.296)\end{array}$ & $\begin{array}{l}0.387^{*} \\
(0.212)\end{array}$ & $\begin{array}{l}0.476^{*} \\
(0.266)\end{array}$ & $\begin{array}{c}0.369 \\
(0.309)\end{array}$ \\
\hline Pens.(0-2)*E. Europe & & $\begin{array}{l}-0.119 \\
(0.173)\end{array}$ & & & $\begin{array}{c}-0.290^{*} \\
(0.148)\end{array}$ & & & $\begin{array}{c}-0.307^{*} \\
(0.172)\end{array}$ & \\
\hline Pens.(3-6)*E. Europe & & $\begin{array}{c}0.00969 \\
(0.104)\end{array}$ & & & $\begin{array}{c}-0.0868 \\
(0.136)\end{array}$ & & & $\begin{array}{l}-0.108 \\
(0.126)\end{array}$ & \\
\hline Pens.(7+)*E. Europe & & $\begin{array}{c}0.202 \\
(0.308)\end{array}$ & & & $\begin{array}{l}-0.324 \\
(0.283)\end{array}$ & & & $\begin{array}{l}-0.375 \\
(0.283)\end{array}$ & \\
\hline Pens.(0-2)*Low Gov. bond & & & $\begin{array}{l}0.0963 \\
(0.181)\end{array}$ & & & $\begin{array}{l}0.0922 \\
(0.171)\end{array}$ & & & $\begin{array}{c}0.107 \\
(0.198)\end{array}$ \\
\hline Pens.(3-6)*Low Gov. bond & & & $\begin{array}{c}0.150 \\
(0.174)\end{array}$ & & & $\begin{array}{l}0.0857 \\
(0.233)\end{array}$ & & & $\begin{array}{l}0.0469 \\
(0.229)\end{array}$ \\
\hline Pens.(7+)*Low Gov. bond & & & $\begin{array}{l}0.0449 \\
(0.364)\end{array}$ & & & $\begin{array}{l}0.0212 \\
(0.321)\end{array}$ & & & $\begin{array}{l}0.0282 \\
(0.325)\end{array}$ \\
\hline Per capita GDP & & & & $\begin{array}{c}13.83 * * * \\
(4.313)\end{array}$ & $\begin{array}{c}14.74^{* * *} \\
(4.211)\end{array}$ & $\begin{array}{c}13.68^{* * *} \\
(4.344)\end{array}$ & $\begin{array}{c}13.83^{* * *} \\
(4.272)\end{array}$ & $\begin{array}{c}14.89 * * * \\
(4.144)\end{array}$ & $\begin{array}{c}13.78^{* * *} \\
(4.316)\end{array}$ \\
\hline Credit to private sector & & & & $\begin{array}{c}-0.0601^{*} \\
(0.0329)\end{array}$ & $\begin{array}{l}-0.0537 \\
(0.0335)\end{array}$ & $\begin{array}{c}-0.0592 * \\
(0.0328)\end{array}$ & $\begin{array}{c}-0.0616 * \\
(0.0329)\end{array}$ & $\begin{array}{c}-0.0547 \\
(0.0334)\end{array}$ & $\begin{array}{c}-0.0611^{*} \\
(0.0327)\end{array}$ \\
\hline Government consumption & & & & $\begin{array}{c}-0.842 * * * \\
(0.162)\end{array}$ & $\begin{array}{c}-0.871^{* * *} \\
(0.169)\end{array}$ & $\begin{array}{c}-0.845^{* * *} \\
(0.163)\end{array}$ & $\begin{array}{c}-0.851 * * * \\
(0.161)\end{array}$ & $\begin{array}{c}-0.884 * * * \\
(0.169)\end{array}$ & $\begin{array}{c}-0.854 * * * \\
(0.163)\end{array}$ \\
\hline Dependency ratio & & & & $\begin{array}{c}0.125 \\
(0.140)\end{array}$ & $\begin{array}{c}0.150 \\
(0.138)\end{array}$ & $\begin{array}{c}0.125 \\
(0.142)\end{array}$ & $\begin{array}{c}0.126 \\
(0.139)\end{array}$ & $\begin{array}{c}0.155 \\
(0.137)\end{array}$ & $\begin{array}{c}0.128 \\
(0.140)\end{array}$ \\
\hline Inflation & & & & $\begin{array}{c}-0.970 \\
(1.274)\end{array}$ & $\begin{array}{l}-1.144 \\
(1.236)\end{array}$ & $\begin{array}{c}-0.951 \\
(1.275)\end{array}$ & $\begin{array}{l}-0.809 \\
(1.222)\end{array}$ & $\begin{array}{c}-0.968 \\
(1.161)\end{array}$ & $\begin{array}{l}-0.776 \\
(1.220)\end{array}$ \\
\hline Terms of trade & & & & $\begin{array}{l}0.0637 * \\
(0.0314)\end{array}$ & $\begin{array}{c}0.0623 * \\
(0.0313)\end{array}$ & $\begin{array}{l}0.0630 * \\
(0.0314)\end{array}$ & $\begin{array}{c}0.0630 * * \\
(0.0308)\end{array}$ & $\begin{array}{c}0.0616 * \\
(0.0309)\end{array}$ & $\begin{array}{l}0.0617^{*} \\
(0.0310)\end{array}$ \\
\hline Unemployment rate & & & & $\begin{array}{c}0.212 \\
(0.186)\end{array}$ & $\begin{array}{c}0.215 \\
(0.189)\end{array}$ & $\begin{array}{c}0.218 \\
(0.186)\end{array}$ & $\begin{array}{c}0.215 \\
(0.184)\end{array}$ & $\begin{array}{c}0.219 \\
(0.188)\end{array}$ & $\begin{array}{c}0.223 \\
(0.185)\end{array}$ \\
\hline Pension(-2to-1) & & & & & & & $\begin{array}{l}-0.144 * \\
(0.0845)\end{array}$ & $\begin{array}{l}-0.159 * \\
(0.0850)\end{array}$ & $\begin{array}{r}-0.0996 \\
(0.146)\end{array}$ \\
\hline Pens.(-2to-1)*E. Europe & & & & & & & & $\begin{array}{l}-0.0560 \\
(0.164)\end{array}$ & \\
\hline Pens(-2to-1)*LowGov. bond & & & & & & & & & $\begin{array}{l}-0.121 \\
(0.171)\end{array}$ \\
\hline Observations & 758 & 758 & 758 & 700 & 700 & 700 & 700 & 700 & 700 \\
\hline Cross sections & 36 & 36 & 36 & 36 & 36 & 36 & 36 & 36 & 36 \\
\hline
\end{tabular}


\begin{tabular}{l|l}
0.093 \\
\hline
\end{tabular}

Time/Country FE

Notes: The dependent variable is the share of gross domestic savings in GDP. The numbers in parentheses are robust clustered standard errors. *, ** and $* * *$ denote significance at $10 \%, 5 \%$ and $1 \%$. Pension reform variables are defined as $\mathrm{P}(0-2)$ equals zero for all years apart from the year of the change in the contribution rate and the subsequent two years; $\mathrm{P}(3-6)$ is non-zero over three to six years following the change and $\mathrm{P}(7 \mathrm{on})$ covers period starting from seven years following the reform. Eastern European is zero-one dummy for Eastern European countries. Low government bond is zero-one dummy for countries and periods in which less than $50 \%$ of total pension fund assets is invested in local government bonds. Per capita GDP is logged. Credit to private sector and Government consumption are defined in share of GDP. Inflation is based on GDP deflator. Terms of trade are defined in percentage change. All macro variables are lagged once. $\mathrm{P}(-2$ to-1) is non-zero for two years that precede the reform. 
Table 8: Savings regressions: Dynamic and long-run regressions:

\begin{tabular}{|c|c|c|c|c|c|c|}
\hline & 1 & 2 & 3 & 4 & 5 & 6 \\
\hline Pension reform & $\begin{array}{c}0.0682 \\
(0.0578)\end{array}$ & $\begin{array}{c}0.0483 \\
(0.0467)\end{array}$ & $\begin{array}{c}0.0383 \\
(0.0498)\end{array}$ & $\begin{array}{c}0.0563 \\
(0.243)\end{array}$ & $\begin{array}{l}-0.0632 \\
(0.239)\end{array}$ & $\begin{array}{l}-0.0213 \\
(0.326)\end{array}$ \\
\hline Pens. ref.*E. Europe & & $\begin{array}{l}-0.0565 \\
(0.0944)\end{array}$ & & & $\begin{array}{c}0.521 \\
(0.463)\end{array}$ & \\
\hline Pens. ref.*Low Gov. bond & & & $\begin{array}{c}0.0498 \\
(0.0957)\end{array}$ & & & $\begin{array}{c}0.215 \\
(0.367)\end{array}$ \\
\hline Per capita GDP (1y) & $\begin{array}{c}2.895^{* *} \\
(1.202)\end{array}$ & $\begin{array}{c}2.827 * * \\
(1.187)\end{array}$ & $\begin{array}{c}2.776^{* *} \\
(1.193)\end{array}$ & & & \\
\hline Lagged change in savings & $\begin{array}{c}0.0536 \\
(0.0364)\end{array}$ & $\begin{array}{c}0.0525 \\
(0.0364)\end{array}$ & $\begin{array}{c}0.0519 \\
(0.0366)\end{array}$ & & & \\
\hline Per capita GDP (5y) & & & & $\begin{array}{c}10.37 * * * \\
(2.939)\end{array}$ & $\begin{array}{c}9.835 * * * \\
(2.967)\end{array}$ & $\begin{array}{c}10.52^{* * * *} \\
(3.073)\end{array}$ \\
\hline Credit to private sector & $\begin{array}{l}-0.0173 * \\
(0.00900)\end{array}$ & $\begin{array}{l}-0.0171^{*} \\
(0.00899)\end{array}$ & $\begin{array}{l}-0.0170 * \\
(0.00901)\end{array}$ & $\begin{array}{c}0.0154 \\
(0.0502)\end{array}$ & $\begin{array}{c}0.0246 \\
(0.0502)\end{array}$ & $\begin{array}{c}0.0107 \\
(0.0536)\end{array}$ \\
\hline Government consumption. & $\begin{array}{c}-0.253^{* * *} \\
(0.0665)\end{array}$ & $\begin{array}{c}-0.244 * * * \\
(0.0647)\end{array}$ & $\begin{array}{c}-0.249 * * * \\
(0.0655)\end{array}$ & $\begin{array}{c}0.0174 \\
(0.225)\end{array}$ & $\begin{array}{l}-0.0391 \\
(0.226)\end{array}$ & $\begin{array}{c}0.0437 \\
(0.243)\end{array}$ \\
\hline Dependency ratio & $\begin{array}{l}0.0541 * \\
(0.0327)\end{array}$ & $\begin{array}{c}0.0511 \\
(0.0319)\end{array}$ & $\begin{array}{c}0.0510 \\
(0.0320)\end{array}$ & $\begin{array}{l}0.0475 \\
(0.178)\end{array}$ & $\begin{array}{c}0.0555 \\
(0.176)\end{array}$ & $\begin{array}{c}0.0612 \\
(0.185)\end{array}$ \\
\hline Inflation & $\begin{array}{c}1.619 * * \\
(0.687)\end{array}$ & $\begin{array}{c}1.622 * * \\
(0.686)\end{array}$ & $\begin{array}{c}1.623^{* *} \\
(0.686)\end{array}$ & $\begin{array}{c}-0.488 \\
(1.833)\end{array}$ & $\begin{array}{c}-0.484 \\
(2.062)\end{array}$ & $\begin{array}{c}-0.464 \\
(2.030)\end{array}$ \\
\hline Terms of trade & $\begin{array}{c}0.0582 * * \\
(0.0240)\end{array}$ & $\begin{array}{c}0.0582 * * \\
(0.0240)\end{array}$ & $\begin{array}{c}0.0577 * * \\
(0.0241)\end{array}$ & $\begin{array}{c}0.654 * * * \\
(0.188)\end{array}$ & $\begin{array}{c}0.692 * * * \\
(0.188)\end{array}$ & $\begin{array}{c}0.633^{* * *} \\
(0.200)\end{array}$ \\
\hline Unemployment rate & $\begin{array}{c}0.128 * * * \\
(0.0475)\end{array}$ & $\begin{array}{c}0.131 * * * \\
(0.0473)\end{array}$ & $\begin{array}{c}0.135^{* * *} \\
(0.0482)\end{array}$ & $\begin{array}{c}0.232 \\
(0.183)\end{array}$ & $\begin{array}{c}0.254 \\
(0.196)\end{array}$ & $\begin{array}{c}0.228 \\
(0.183)\end{array}$ \\
\hline Observations & 686 & 686 & 686 & 123 & 123 & 123 \\
\hline Cross section & 36 & 36 & 36 & 36 & 36 & 36 \\
\hline $\mathrm{R} 2$ & & & & 0.561 & 0.576 & 0.565 \\
\hline Adjusted R2 & & & & 0.518 & 0.529 & 0.517 \\
\hline Time/Country FE & Yes/Yes & Yes/Yes & Yes/Yes & Yes/No & Yes/No & Yes/No \\
\hline
\end{tabular}

Notes: The dependent variable in columns (1-3) is the change in the savings to GDP ratio.. The dependent variable in columns (4-6) is the average share of gross domestic savings in GDP over five year windows. The numbers in parentheses are bootstrap standard errors. *, ** and *** denote significance at $10 \%, 5 \%$ and $1 \%$. Pension reform variable is defined equal zero or the second pillar contribution rate. Eastern European is zero-one dummy for Eastern European countries. Low government bond is zero-one dummy for countries and periods in which less than $50 \%$ of total pension fund assets is invested in local government bonds. The pension reform variables in columns (4-6) are lagged 5 years (the start of the window). The macro explanatory variables in columns (1-3) are lagged once. The macro explanatory variables in columns (4-6) are lagged five year averages. Per capita GDP and dependency ratio in columns (4-6) enter with 5 year lag. Coefficients for the changes in the covariates in columns (1-3) are not reported to save space. 


\section{Appendix}

This Appendix reports results from several additional robustness checks.

Tables A1 and A4 report the two-stage estimates of the growth and savings regressions, respectively. In particular, given the censored character of the pension reform variable, we estimate the first-stage Tobit regressions and use generalized residuals from the first-stage model as an additional explanatory variable in the second-stage regressions. Following Reece and Sam (2012), as the first-stage instruments we use the expected increase in the pensioner to worker ratio (which we proxy with the 20-year difference in the old age dependency ratio, Lane and Milessi-Ferretti, 2012) and the number of regional peer countries that have enacted privatization by the given year of the observation. The results from the first-stage regressions are reported in the first columns of Tables A1 and A4, while the remaining columns report the second-stage estimates. We bootstrap the standard errors and use interaction of the instruments with the dummies as instruments for the pension interaction terms. The first-stage estimates suggest that both instruments are statistically significant and enter with the expected sign, analogous to Reece and Sam (2012). A higher expected increase in the pensioner to worker ratio decreases the share of the employee's wage that is allocated to private funds in the second pillar to accommodate a higher transitional deficit due to the larger number of pensioners. The higher number of similar countries that have enacted privatization reduces the uncertainty associated with the reform and has a positive impact on the reform. The remaining columns of Tables A1 and A4 show that the second-stage estimates of pension privatization impact do not deviate from earlier findings. ${ }^{21}$ In addition, the coefficients for generalized residuals are not statistically significant, suggesting that the use of fixed effects and our construction of the pension reform variable control for potential endogeneity.

Tables A2 and A5 report the pooled estimates of broader growth and savings regressions, respectively. The idea is to assess the sensitivity of the main results with respect to the fixed effect assumptions. The inclusion of country fixed effects (while controlling for the timeinvariant drivers of economic development) may drive the results to the extent that the withinvariation in the pension variable may be insufficiently large to allow capturing the growth and savings effects of privatization. Analogously, time fixed effects may capture the positive growth effects of pension privatization if the reforms were implemented in the same year across a number of countries. The results from the regressions remain broadly the same as in the baseline estimations, in line with the fact that the timing of the pension reform was heterogeneously spread over our sample period, the only exceptions being 1998 and 2002, when three countries initiated the reform. The only difference to our previous results is that the coefficient on $\mathrm{P}_{\mathrm{it}}{ }^{0-2}$ is positive and statistically significant in growth regressions when all fixed effects are excluded. However, the positive impact on growth and savings is absent in all other regressions.

\footnotetext{
${ }^{21}$ We do not estimate two-stage time varying regressions, as this would require controlling for three to six endogenous regressors. The pension reform variable enters long-run regressions with a lag, which mitigates reverse causality issues.
} 
Finally, Table A3 reports the results from a small Monte Carlo experiment where we use actual data on the pension reform variable and generate 5,000 artificial datasets of the same size as our actual dataset, allowing for fixed effects, exogenous covariates, and within-cluster autocorrelation and heteroscedasticity. We run several experiments for static and time-varying fixed effects estimators ${ }^{22}: 1$ ) set the coefficient for pension variables equal to zero to assess the performance of the estimators and empirical size of the corresponding t-statistic; 2) vary the positive value of the pension variable coefficient and examine the empirical power of the tstatistic based on static and time-varying estimators; 3) allow that pension reform only has a significant impact in the long run. The results show that the parameters are tightly estimated and the t-test of the statistical significance of the pension variable is not oversized (Column 1). As expected, the power of the t-test increases with the magnitude of the coefficient on the pension reform variable, but even for assumed values of the parameters that imply small economic effects (0.05), the power of the test is above $50 \%$ and very quickly reaches $95 \%$ (Column 2-4). Overall, the Monte Carlo results imply that small sample issues are unlikely to drive our findings, even when fixed effects are included.

\footnotetext{
${ }^{22}$ We leave simulations of the dynamic model for future research, as each Monte Carlo repetition requires a nested bootstrap loop of the dynamic model in order to obtain the estimates of the standard errors and the corresponding t-statistics.
} 
Table A1: Growth regressions: Two stage estimates:

\begin{tabular}{|c|c|c|c|c|c|c|c|}
\hline Variable & 1 & 2 & 3 & 4 & 5 & 6 & 7 \\
\hline Pension reform & & $\begin{array}{l}-0.0198 \\
(0.142)\end{array}$ & $\begin{array}{l}-0.0813 \\
(0.760)\end{array}$ & $\begin{array}{l}-0.0657 \\
(0.518)\end{array}$ & $\begin{array}{l}-0.0569 \\
(0.099)\end{array}$ & $\begin{array}{l}-0.0622 \\
(0.171)\end{array}$ & $\begin{array}{l}-0.0755 \\
(0.132)\end{array}$ \\
\hline Pension ref.*E. Europe & & & $\begin{array}{l}0.0901 \\
(0.775)\end{array}$ & & & $\begin{array}{l}-0.109 \\
(0.212)\end{array}$ & \\
\hline Pension ref.*Low Gov. bond & & & & $\begin{array}{l}0.0933 \\
(0.222)\end{array}$ & & & $\begin{array}{c}-0.0362 \\
(0.191)\end{array}$ \\
\hline Aging speed & $\begin{array}{c}-0.227^{*} \\
(0.131)\end{array}$ & & & & & & \\
\hline Peers & $\begin{array}{c}0.464^{* * *} \\
(0.0567)\end{array}$ & & & & & & \\
\hline Per capita GDP & $\begin{array}{c}5.285^{* * *} \\
(1.706)\end{array}$ & $\begin{array}{c}-12.08 * * * \\
(2.109)\end{array}$ & $\begin{array}{c}-12.32 * * * \\
(4.169)\end{array}$ & $\begin{array}{c}-12.26 * * * \\
(2.820)\end{array}$ & $\begin{array}{c}-7.835 * * * \\
(2.053)\end{array}$ & $\begin{array}{c}-8.932 * * * \\
(2.724)\end{array}$ & $\begin{array}{c}-8.552 * * * \\
(2.165)\end{array}$ \\
\hline Investment & $\begin{array}{c}0.0654 \\
(0.0555)\end{array}$ & $\begin{array}{c}0.139 * * * \\
(0.0479)\end{array}$ & $\begin{array}{c}0.139 * \\
(0.0779)\end{array}$ & $\begin{array}{c}0.120 \\
(0.0916)\end{array}$ & $\begin{array}{c}0.200 * * * \\
(0.065)\end{array}$ & $\begin{array}{c}0.185^{* *} \\
(0.084)\end{array}$ & $\begin{array}{c}0.204^{* * *} \\
(0.067)\end{array}$ \\
\hline Government consump. & $\begin{array}{r}-0.0292 \\
(0.119)\end{array}$ & $\begin{array}{c}-0.280 * * * \\
(0.0997)\end{array}$ & $\begin{array}{l}-0.260 \\
(0.160)\end{array}$ & $\begin{array}{l}-0.295 \\
(0.273)\end{array}$ & $\begin{array}{c}-0.270 * * \\
(0.113)\end{array}$ & $\begin{array}{c}-0.234 \\
(0.149)\end{array}$ & $\begin{array}{c}-0.319 * * * \\
(0.113)\end{array}$ \\
\hline Inflation & $\begin{array}{c}-6.747 * * * \\
(1.763)\end{array}$ & $\begin{array}{l}-2.152 \\
(1.366)\end{array}$ & $\begin{array}{l}-1.769 \\
(7.340)\end{array}$ & $\begin{array}{l}-2.263 \\
(4.030)\end{array}$ & $\begin{array}{l}-2.447 \\
(1.546)\end{array}$ & $\begin{array}{c}1.350 \\
(4.935)\end{array}$ & $\begin{array}{l}-2.715 \\
(1.771)\end{array}$ \\
\hline Male upp. lev. schooling & $\begin{array}{c}0.967 \\
(0.740)\end{array}$ & $\begin{array}{l}-0.765 \\
(1.052)\end{array}$ & $\begin{array}{c}-0.863 \\
(1.201)\end{array}$ & $\begin{array}{c}-0.994 \\
(1.512)\end{array}$ & $\begin{array}{c}0.0598 * \\
(0.034)\end{array}$ & $\begin{array}{c}0.0744^{*} \\
(0.045)\end{array}$ & $\begin{array}{l}0.0580 \\
(0.038)\end{array}$ \\
\hline Life expectancy at birth & $\begin{array}{c}-0.930 * * * \\
(0.235)\end{array}$ & $\begin{array}{l}-0.492 \\
(0.362)\end{array}$ & $\begin{array}{l}-0.459 \\
(0.506)\end{array}$ & $\begin{array}{l}-0.436 \\
(0.561)\end{array}$ & $\begin{array}{c}-0.00116 \\
(0.089)\end{array}$ & $\begin{array}{l}-0.0919 \\
(0.269)\end{array}$ & $\begin{array}{c}0.00625 \\
(0.107)\end{array}$ \\
\hline Polity index & $\begin{array}{c}0.0192 \\
(0.0253)\end{array}$ & $\begin{array}{c}0.0231 \\
(0.0661)\end{array}$ & $\begin{array}{l}0.0156 \\
(0.752)\end{array}$ & $\begin{array}{l}0.0242 \\
(0.138)\end{array}$ & $\begin{array}{l}-0.375 \\
(0.311)\end{array}$ & $\begin{array}{c}-0.282 \\
(0.395)\end{array}$ & $\begin{array}{l}-0.355 \\
(0.286)\end{array}$ \\
\hline Terms of trade & $\begin{array}{l}0.00245 \\
(0.0282)\end{array}$ & $\begin{array}{l}0.0328 * \\
(0.0181)\end{array}$ & $\begin{array}{c}0.0334 \\
(0.0361)\end{array}$ & $\begin{array}{c}0.0307 \\
(0.0286)\end{array}$ & $\begin{array}{c}-0.0868 \\
(0.908)\end{array}$ & $\begin{array}{l}-0.292 \\
(0.963)\end{array}$ & $\begin{array}{l}-0.381 \\
(0.924)\end{array}$ \\
\hline Trade openness & $\begin{array}{l}0.00652 \\
(0.0151)\end{array}$ & $\begin{array}{c}0.0109 \\
(0.0144)\end{array}$ & $\begin{array}{l}0.00900 \\
(0.0208)\end{array}$ & $\begin{array}{c}0.0115 \\
(0.0194)\end{array}$ & $\begin{array}{c}0.00659 \\
(0.017)\end{array}$ & $\begin{array}{c}0.00712 \\
(0.017)\end{array}$ & $\begin{array}{c}0.00868 \\
(0.017)\end{array}$ \\
\hline Lagged pc GDP growth & & & & & $\begin{array}{c}0.185^{* * *} \\
(0.071)\end{array}$ & $\begin{array}{c}0.170 * * \\
(0.073)\end{array}$ & $\begin{array}{c}0.169 * * \\
(0.072)\end{array}$ \\
\hline Residual Pension ref. & & $\begin{array}{c}0.125 \\
(0.457)\end{array}$ & $\begin{array}{c}0.224 \\
(0.785)\end{array}$ & $\begin{array}{c}-0.00633 \\
(0.966)\end{array}$ & $\begin{array}{l}0.0341 \\
(0.351)\end{array}$ & $\begin{array}{l}-0.0896 \\
(0.431)\end{array}$ & $\begin{array}{l}-0.135 \\
(0.404)\end{array}$ \\
\hline Residual Pens. ref.*E. Europe & & & $\begin{array}{l}0.0676 \\
(0.654)\end{array}$ & & & $\begin{array}{c}0.714 \\
(0.574)\end{array}$ & \\
\hline Residual Pens. ref.*Gov. bond & & & & $\begin{array}{c}0.477 \\
(0.504)\end{array}$ & & & $\begin{array}{c}0.742 \\
(0.556)\end{array}$ \\
\hline Observations & 636 & 636 & 636 & 636 & 636 & 636 & 636 \\
\hline Cross sections & 33 & 33 & 33 & 33 & 33 & 33 & 33 \\
\hline Time/Country FE & Yes/No & Yes/Yes & Yes/Yes & Yes/Yes & Yes/Yes & Yes/Yes & Yes/Yes \\
\hline
\end{tabular}

Notes: The dependent variable in columns (1) is Pension reform (first stage estimates). The dependent variable in columns (2-7) is the annual growth rate of real GDP per capita multiplied by 100 (second stage). Columns (2-4) report estimates from static fixed effect model. Columns (5-7) report estimates from dynamic fixed effect model The numbers in parentheses are bootstrap standard errors.*, ** and *** denote significance at $10 \%, 5 \%$ and $1 \%$. Old age speed and Peers are used as instruments in the first stage. All covariates are as in the main text. Residual pension ref is generalized residual from the first stage Tobit regression with Pension reform as the dependent variable (column 1). Residual pension ref E.Europe (Gov. bond) is generalized residual from Tobit regression with interaction term Pension reform*Eastern Europe (High share of government bonds) as the dependent variable (not reported). 
Table A2: Growth regressions: Removing fixed effects:

\begin{tabular}{|c|c|c|c|c|c|c|c|c|c|}
\hline Variable & 1 & 2 & 3 & 4 & 5 & 6 & 7 & 8 & 9 \\
\hline Pension reform & $\begin{array}{l}-0.0126 \\
(0.0372)\end{array}$ & $\begin{array}{c}0.0132 \\
(0.0507)\end{array}$ & $\begin{array}{l}-0.0428 \\
(0.0498)\end{array}$ & & & & $\begin{array}{l}-0.0181 \\
(0.0523)\end{array}$ & $\begin{array}{l}-0.0601 \\
(0.0616)\end{array}$ & $\begin{array}{l}-0.0741 \\
(0.0609)\end{array}$ \\
\hline Pension ref.*E. Europe & & $\begin{array}{c}0.0981 \\
(0.0852)\end{array}$ & & & & & & $\begin{array}{c}0.136 \\
(0.105)\end{array}$ & \\
\hline $\begin{array}{l}\text { Pension ref.*Low Gov. } \\
\text { bond }\end{array}$ & & & 0.0663 & & & & & & $0.201 *$ \\
\hline & & & $(0.0576)$ & & & & & & $(0.105)$ \\
\hline Pension $(0-2)$ & & & & $\begin{array}{l}0.112 * * \\
(0.0520)\end{array}$ & $\begin{array}{c}0.0693 \\
(0.0537)\end{array}$ & $\begin{array}{c}0.0128 \\
(0.0659)\end{array}$ & & & \\
\hline Pension (3-6) & & & & $\begin{array}{c}-0.115 \\
(0.0715)\end{array}$ & $\begin{array}{l}-0.0969 \\
(0.0668)\end{array}$ & $\begin{array}{l}-0.137 \\
(0.118)\end{array}$ & & & \\
\hline Pension (7+) & & & & $\begin{array}{l}-0.0438 \\
(0.0618)\end{array}$ & $\begin{array}{c}0.0835 \\
(0.0585)\end{array}$ & $\begin{array}{c}-0.0184 \\
(0.0809)\end{array}$ & & & \\
\hline Pens.(0-2)*E. Europe & & & & & $\begin{array}{c}0.121 \\
(0.166)\end{array}$ & & & & \\
\hline Pens.(3-6)*E. Europe & & & & & $\begin{array}{c}-0.0765 \\
(0.178)\end{array}$ & & & & \\
\hline Pens.(7+)*E. Europe & & & & & $\begin{array}{c}-0.312^{* * *} \\
(0.104)\end{array}$ & & & & \\
\hline Pens.(0-2)*Low Gov. bond & & & & & & $\begin{array}{c}0.223 * * \\
(0.102)\end{array}$ & & & \\
\hline Pens.(3-6)*Low Gov. bond & & & & & & $\begin{array}{l}0.0325 \\
(0.132)\end{array}$ & & & \\
\hline Pens.(7+)*Low Gov. bond & & & & & & $\begin{array}{l}-0.0675 \\
(0.0964)\end{array}$ & & & \\
\hline Per capita GDP & $\begin{array}{c}-1.416^{* * *} \\
(0.502)\end{array}$ & $\begin{array}{c}-1.655^{* * *} \\
(0.465)\end{array}$ & $\begin{array}{c}-1.361 * * \\
(0.517)\end{array}$ & $\begin{array}{c}-1.371^{* * *} \\
(0.478)\end{array}$ & $\begin{array}{c}-1.138 * * \\
(0.497)\end{array}$ & $\begin{array}{c}-1.350^{* * *} \\
(0.477)\end{array}$ & $\begin{array}{c}-5.447 * * * \\
(1.352)\end{array}$ & $\begin{array}{c}-5.615^{* * *} \\
(1.350)\end{array}$ & $\begin{array}{c}-5.756 * * * \\
(1.352)\end{array}$ \\
\hline Investment & $\begin{array}{c}-0.0461 \\
(0.0396)\end{array}$ & $\begin{array}{c}-0.0758 * \\
(0.0386)\end{array}$ & $\begin{array}{l}-0.0548 \\
(0.0402)\end{array}$ & $\begin{array}{l}-0.0553 \\
(0.0383)\end{array}$ & $\begin{array}{c}-0.0898 * * \\
(0.0366)\end{array}$ & $\begin{array}{c}-0.0661 \\
(0.0394)\end{array}$ & $\begin{array}{c}0.175^{* * *} \\
(0.0469)\end{array}$ & $\begin{array}{c}0.176^{* * *} \\
(0.0470)\end{array}$ & $\begin{array}{c}0.175^{* * *} \\
(0.0468)\end{array}$ \\
\hline Government consump. & $\begin{array}{l}-0.0102 \\
(0.0570)\end{array}$ & $\begin{array}{l}-0.0557 \\
(0.0584)\end{array}$ & $\begin{array}{l}-0.0103 \\
(0.0582)\end{array}$ & $\begin{array}{l}-0.00950 \\
(0.0545)\end{array}$ & $\begin{array}{l}-0.0697 \\
(0.0647)\end{array}$ & $\begin{array}{l}-0.0111 \\
(0.0531)\end{array}$ & $\begin{array}{l}-0.211^{* *} \\
(0.0892)\end{array}$ & $\begin{array}{l}-0.193 * * \\
(0.0914)\end{array}$ & $\begin{array}{l}-0.226^{* *} \\
(0.0886)\end{array}$ \\
\hline Inflation & $\begin{array}{l}-1.007 \\
(1.096)\end{array}$ & $\begin{array}{l}-0.929 \\
(1.089)\end{array}$ & $\begin{array}{l}-1.067 \\
(1.111)\end{array}$ & $\begin{array}{l}-1.178 \\
(1.106)\end{array}$ & $\begin{array}{l}-1.190 \\
(1.133)\end{array}$ & $\begin{array}{l}-1.265 \\
(1.124)\end{array}$ & $\begin{array}{c}-1.957^{* *} \\
(0.836)\end{array}$ & $\begin{array}{c}-1.886^{* *} \\
(0.839)\end{array}$ & $\begin{array}{c}-2.079 * * \\
(0.842)\end{array}$ \\
\hline Male upp. lev. schooling & $\begin{array}{c}1.095^{* * *} \\
(0.208)\end{array}$ & $\begin{array}{c}0.643 * * \\
(0.251)\end{array}$ & $\begin{array}{c}1.087^{* * *} \\
(0.213)\end{array}$ & $\begin{array}{c}1.124^{* * *} \\
(0.205)\end{array}$ & $\begin{array}{c}0.694 * * \\
(0.269)\end{array}$ & $\begin{array}{c}1.126^{* * *} \\
(0.204)\end{array}$ & $\begin{array}{c}0.0908 * * * \\
(0.0294)\end{array}$ & $\begin{array}{c}0.0904 * * * \\
(0.0295)\end{array}$ & $\begin{array}{c}0.0868 * * * \\
(0.0294)\end{array}$ \\
\hline Life expectancy at birth & $\begin{array}{c}0.0709 \\
(0.0700)\end{array}$ & $\begin{array}{c}0.118^{*} \\
(0.0673)\end{array}$ & $\begin{array}{c}0.0616 \\
(0.0733)\end{array}$ & $\begin{array}{c}0.0831 \\
(0.0687)\end{array}$ & $\begin{array}{c}0.0631 \\
(0.0796)\end{array}$ & $\begin{array}{c}0.0878 \\
(0.0684)\end{array}$ & $\begin{array}{l}-0.0121 \\
(0.0281)\end{array}$ & $\begin{array}{l}-0.0149 \\
(0.0280)\end{array}$ & $\begin{array}{c}-0.00903 \\
(0.0282)\end{array}$ \\
\hline
\end{tabular}




\begin{tabular}{|c|c|c|c|c|c|c|c|c|c|}
\hline Polity index & $\begin{array}{c}0.0322 * * \\
(0.0133)\end{array}$ & $\begin{array}{c}0.0296 * * \\
(0.0134)\end{array}$ & $\begin{array}{c}0.0320^{* *} \\
(0.0131)\end{array}$ & $\begin{array}{l}0.0284 * \\
(0.0147)\end{array}$ & $\begin{array}{c}0.0147 \\
(0.0207)\end{array}$ & $\begin{array}{c}0.0295 * * \\
(0.0143)\end{array}$ & $\begin{array}{l}0.266^{*} \\
(0.154)\end{array}$ & $\begin{array}{c}0.314^{* *} \\
(0.155)\end{array}$ & $\begin{array}{l}0.296 * \\
(0.154)\end{array}$ \\
\hline Terms of trade & $\begin{array}{c}0.0577 * * * \\
(0.0188)\end{array}$ & $\begin{array}{c}0.0639 * * * \\
(0.0193)\end{array}$ & $\begin{array}{c}0.0566 * * * \\
(0.0188)\end{array}$ & $\begin{array}{c}0.0580^{* * * *} \\
(0.0191)\end{array}$ & $\begin{array}{c}0.0536 * * \\
(0.0201)\end{array}$ & $\begin{array}{c}0.0572 * * * \\
(0.0195)\end{array}$ & $\begin{array}{c}0.931 \\
(0.590)\end{array}$ & $\begin{array}{c}0.793 \\
(0.603)\end{array}$ & $\begin{array}{c}0.772 \\
(0.600)\end{array}$ \\
\hline Trade openness & $\begin{array}{l}-0.00241 \\
(0.00594)\end{array}$ & $\begin{array}{l}-0.00167 \\
(0.00695)\end{array}$ & $\begin{array}{l}-0.00201 \\
(0.00608)\end{array}$ & $\begin{array}{l}-0.00278 \\
(0.00565)\end{array}$ & $\begin{array}{c}0.00248 \\
(0.00725)\end{array}$ & $\begin{array}{l}-0.00335 \\
(0.00571)\end{array}$ & $\begin{array}{c}0.00276 \\
(0.0112)\end{array}$ & $\begin{array}{c}0.0000888 \\
(0.0112)\end{array}$ & $\begin{array}{l}0.00275 \\
(0.0112)\end{array}$ \\
\hline Observations & 636 & 636 & 636 & 636 & 636 & 636 & 634 & 634 & 634 \\
\hline Cross sections & 33 & 33 & 33 & 33 & 33 & 33 & 33 & 33 & 33 \\
\hline $\mathrm{R} 2$ & 0.101 & 0.120 & 0.103 & 0.117 & 0.148 & 0.125 & & & \\
\hline Adjusted R2 & 0.087 & 0.103 & 0.087 & 0.100 & 0.126 & 0.104 & & & \\
\hline Time/Country FE & No/No & No/No & No/No & No/No & No/No & No/No & No/Yes & $\mathrm{No} / \mathrm{Yes}$ & No/Yes \\
\hline
\end{tabular}

Notes: The dependent variable is the annual growth rate of real GDP per capita multiplied by 100. Columns (1-3) report estimates from static regressions without fixed effects. Columns (4-6) report estimates from model with time-varying effects. Columns (7-9) report estimates from dynamic model The numbers in parentheses are robust clustered standard errors (1-6) and bootstrap standard errors (7$9) . *, * *$ and $* * *$ denote significance at $10 \%, 5 \%$ and $1 \%$. All covariates are as in the main text. 
Table A3: Monte Carlo results:

\begin{tabular}{|c|c|c|c|c|}
\hline Parameter value & $\mathbf{0}$ & 0.05 & 0.1 & \\
\hline \multicolumn{5}{|l|}{ Pension reform } \\
\hline Coefficient & 0.001 & 0.0497 & 0.099 & \\
\hline $90 \%$ coverage & {$\left[\begin{array}{lll}-0.036 & 0.037\end{array}\right]$} & [ 0.013 0.087 $]$ & {$\left[\begin{array}{ll}0.064 & 0.136\end{array}\right]$} & \\
\hline t-stat & 0.108 & 0.712 & 0.998 & \\
\hline Parameter values & $0 ; 0 ; 0$ & $0.05 ; 0.05 ; 0.05$ & $0.075 ; 0.075 ; 0.1$ & $0 ; 0 ; 0.1$ \\
\hline \multicolumn{5}{|l|}{ Pension (0-2) } \\
\hline Coefficient & 0.000 & 0.050 & 0.075 & 0.000 \\
\hline $90 \%$ coverage & {$\left[\begin{array}{lll}-0.047 & 0.047]\end{array}\right]$} & {$\left[\begin{array}{lll}0.004 & 0.097\end{array}\right]$} & [0.029 0.121$]$ & {$\left[\begin{array}{ll}-0.046 & 0.045\end{array}\right]$} \\
\hline t-stat & 0.103 & 0.527 & 0.831 & 0.096 \\
\hline \multicolumn{5}{|l|}{ Pension (3-6) } \\
\hline Coefficient & 0.000 & 0.050 & 0.075 & 0.000 \\
\hline $90 \%$ coverage & {$\left[\begin{array}{lll}-0.045 & 0.046\end{array}\right]$} & [ 0.005 0.095] & {$\left[\begin{array}{ll}0.031 & 0.119\end{array}\right]$} & {$\left[\begin{array}{ll}-0.046 & 0.045\end{array}\right]$} \\
\hline t-stat & 0.112 & 0.571 & 0.858 & 0.110 \\
\hline \multicolumn{5}{|l|}{ Pension (7+) } \\
\hline Coefficient & 0.001 & 0.050 & 0.100 & 0.100 \\
\hline $90 \%$ coverage & {$\left[\begin{array}{lll}-0.042 & 0.043]\end{array}\right]$} & {$\left[\begin{array}{ll}0.008 & 0.092\end{array}\right]$} & {$\left[\begin{array}{ll}0.058 & 0.142\end{array}\right]$} & {$\left[\begin{array}{lll}0.059 & 0.141]\end{array}\right]$} \\
\hline t-stat & 0.103 & 0.614 & 0.987 & 0.986 \\
\hline
\end{tabular}

Notes: Each row reports Monte Carlo coefficient estimate, 90\% Monte Carlo coverage and the percentage of rejections of the null hypothesis of the simple t-test at the $10 \%$ significance level. Each column within two panels (top and bottom) reports results from one experiment. The top panel reports results from the static fixed effect regressions where Pension reform variable takes three alternative values given in column heading. The lower panel reports results from time-varying fixed effect regressions where pension reform variables are defined as $\mathrm{P}(0-2)$ equals zero for all years apart from the year of the change in the contribution rate and the subsequent two years; $\mathrm{P}(3-6)$ is non-zero over three to six years following the change and $\mathrm{P}(7 \mathrm{on})$ covers period starting from seven years following the reform. The true values of the variables are given in the column heading for each experiment. Each experiment uses 5000 simulations. 
Table A4: Savings regressions: Two stage estimates:

\begin{tabular}{|c|c|c|c|c|c|c|c|}
\hline Variable & 1 & 2 & 3 & 4 & 5 & 6 & 7 \\
\hline Pension reform & & $\begin{array}{c}0.228 \\
(0.355)\end{array}$ & $\begin{array}{c}0.384 \\
(0.540)\end{array}$ & $\begin{array}{c}0.210 \\
(1.077)\end{array}$ & $\begin{array}{c}0.128 \\
(0.174)\end{array}$ & $\begin{array}{c}0.168 \\
(0.187)\end{array}$ & $\begin{array}{l}0.0860 \\
(0.178)\end{array}$ \\
\hline Pension ref.*E. Europe & & & $\begin{array}{l}-0.261 \\
(0.660)\end{array}$ & & & $\begin{array}{r}-0.0955 \\
(0.229)\end{array}$ & \\
\hline Pension ref.*Low Gov. bond & & & & $\begin{array}{c}0.188 \\
(0.635)\end{array}$ & & & $\begin{array}{c}0.177 \\
(0.185)\end{array}$ \\
\hline Aging speed & $\begin{array}{c}-0.254^{*} \\
(0.147)\end{array}$ & & & & & & \\
\hline Peers & $\begin{array}{c}0.323^{* * * *} \\
(0.0569)\end{array}$ & & & & & & \\
\hline Per capita GDP & $\begin{array}{c}4.229 * * * \\
(1.436)\end{array}$ & $\begin{array}{c}13.47 * * * \\
(4.989)\end{array}$ & $\begin{array}{c}14.13^{* * *} \\
(5.307)\end{array}$ & $\begin{array}{c}13.71 \\
(8.819)\end{array}$ & $\begin{array}{c}2.497 * * \\
(1.20)\end{array}$ & $\begin{array}{c}2.488 * * \\
(1.17)\end{array}$ & $\begin{array}{c}2.908 * * \\
(1.365)\end{array}$ \\
\hline Credit to private sector & $\begin{array}{c}0.00794 \\
(0.0134)\end{array}$ & $\begin{array}{c}-0.0688 * \\
(0.0360)\end{array}$ & $\begin{array}{c}-0.0675 * \\
(0.0350)\end{array}$ & $\begin{array}{c}-0.0736 \\
(0.0491)\end{array}$ & $\begin{array}{l}-0.0170 \\
(0.012)\end{array}$ & $\begin{array}{r}-0.0171 \\
(0.011)\end{array}$ & $\begin{array}{l}-0.0200 \\
(0.014)\end{array}$ \\
\hline Government consump. & $\begin{array}{c}-0.234^{* *} \\
(0.116)\end{array}$ & $\begin{array}{c}-0.856^{* * *} \\
(0.183)\end{array}$ & $\begin{array}{c}-0.914 * * * \\
(0.194)\end{array}$ & $\begin{array}{c}-0.863 * \\
(0.464)\end{array}$ & $\begin{array}{c}-0.239 * \\
(0.145)\end{array}$ & $\begin{array}{c}-0.241 \\
(0.159)\end{array}$ & $\begin{array}{l}-0.226 \\
(0.155)\end{array}$ \\
\hline Dependancy ratio & $\begin{array}{c}-0.0792 \\
(0.0805)\end{array}$ & $\begin{array}{c}0.174 \\
(0.160)\end{array}$ & $\begin{array}{c}0.172 \\
(0.178)\end{array}$ & $\begin{array}{c}0.197 \\
(0.354)\end{array}$ & $\begin{array}{l}0.0654 \\
(0.052)\end{array}$ & $\begin{array}{l}0.0631 \\
(0.056)\end{array}$ & $\begin{array}{l}0.0780 \\
(0.058)\end{array}$ \\
\hline Inflation & $\begin{array}{c}-5.783^{* * *} \\
(1.700)\end{array}$ & $\begin{array}{l}-1.663 \\
(1.919)\end{array}$ & $\begin{array}{l}-2.540 \\
(2.937)\end{array}$ & $\begin{array}{l}-1.432 \\
(11.75)\end{array}$ & $\begin{array}{c}1.531 \\
(1.458)\end{array}$ & $\begin{array}{c}1.661 \\
(1.548)\end{array}$ & $\begin{array}{c}1.800 \\
(1.610)\end{array}$ \\
\hline Terms of trade & $\begin{array}{c}-0.00756 \\
(0.0292)\end{array}$ & $\begin{array}{c}0.0709 * * \\
(0.0325)\end{array}$ & $\begin{array}{c}0.0742 * * \\
(0.0357)\end{array}$ & $\begin{array}{c}0.0702 \\
(0.0964)\end{array}$ & $\begin{array}{l}0.0566 \\
(0.039)\end{array}$ & $\begin{array}{c}0.0567 * \\
(0.034)\end{array}$ & $\begin{array}{l}0.0545 \\
(0.039)\end{array}$ \\
\hline Unemployment rate & $\begin{array}{c}0.126^{*} \\
(0.0692)\end{array}$ & $\begin{array}{c}0.192 \\
(0.195)\end{array}$ & $\begin{array}{c}0.176 \\
(0.202)\end{array}$ & $\begin{array}{c}0.167 \\
(0.330)\end{array}$ & $\begin{array}{l}0.134 * \\
(0.081)\end{array}$ & $\begin{array}{c}0.131 \\
(0.083)\end{array}$ & $\begin{array}{l}0.132 * \\
(0.080)\end{array}$ \\
\hline Residual Pension ref. & & $\begin{array}{l}-0.930 \\
(1.048)\end{array}$ & $\begin{array}{l}-0.900 \\
(1.242)\end{array}$ & $\begin{array}{l}-0.723 \\
(3.037)\end{array}$ & $\begin{array}{l}-0.360 \\
(0.387)\end{array}$ & $\begin{array}{l}-0.432 \\
(0.574)\end{array}$ & $\begin{array}{l}-0.169 \\
(0.411)\end{array}$ \\
\hline $\begin{array}{l}\text { Residual Pens. ref.*E. } \\
\text { Europe }\end{array}$ & & & $\begin{array}{l}-0.285 \\
(1.034)\end{array}$ & & & $\begin{array}{l}0.0964 \\
(0.459)\end{array}$ & \\
\hline $\begin{array}{l}\text { Residual Pens. ref.*Gov. } \\
\text { bond }\end{array}$ & & & & $\begin{array}{l}-0.412 \\
(1.365)\end{array}$ & & & $\begin{array}{l}-0.572 \\
(0.363)\end{array}$ \\
\hline Observations & 700 & 700 & 700 & 700 & 700 & 700 & 700 \\
\hline Cross sections & 36 & 36 & 36 & 36 & 36 & 36 & 36 \\
\hline Time/Country FE & Yes/No & Yes/Yes & Yes/Yes & Yes/Yes & Yes/Yes & Yes/Yes & Yes/Yes \\
\hline
\end{tabular}

Notes: The dependent variable in columns (1) is Pension reform (first stage estimates). The dependent variable in columns (2-4) is the share of gross domestic savings in GDP (second stage).The dependent variable in columns (5-7) is the change in the share of gross domestic savings in GDP (second stage). Columns (2-4) report estimates from static fixed effect model. Columns (5-7) report estimates from dynamic fixed effect model The numbers in parentheses are bootstrap standard errors.*, ** and *** denote significance at $10 \%, 5 \%$ and $1 \%$. Old age speed and Peers are used as instruments in the first stage. All covariates are as in the main text. Residual pension ref is generalized residual from the first stage Tobit regression with Pension reform as the dependent variable (column 1). Residual pension ref E.Europe (Gov. bond) is generalized residual from Tobit regression with interaction term Pension reform*Eastern Europe (High share of government bonds) as the dependent variable (not reported). 
Table A5: Savings regressions: Removing fixed effects:

\begin{tabular}{|c|c|c|c|c|c|c|c|c|c|}
\hline Variable & 1 & 2 & 3 & 4 & 5 & 6 & 7 & 8 & 9 \\
\hline Pension reform & $\begin{array}{c}-0.0203 \\
(0.248)\end{array}$ & $\begin{array}{c}-0.165 \\
(0.298)\end{array}$ & $\begin{array}{c}-0.211 \\
(0.352)\end{array}$ & & & & $\begin{array}{c}0.0548 \\
(0.0443)\end{array}$ & $\begin{array}{c}0.0734 \\
(0.0538)\end{array}$ & $\begin{array}{c}0.0667 \\
(0.0496)\end{array}$ \\
\hline Pension ref.*E. Europe & & $\begin{array}{c}0.432 \\
(0.439)\end{array}$ & & & & & & $\begin{array}{c}-0.0553 \\
(0.0907)\end{array}$ & \\
\hline $\begin{array}{l}\text { Pension ref.*Low Gov. } \\
\text { bond }\end{array}$ & & & 0.414 & & & & & & -0.0406 \\
\hline Pension (3-6) & & & & $\begin{array}{c}-0.261 \\
(0.202)\end{array}$ & $\begin{array}{l}-0.269 \\
(0.208)\end{array}$ & $\begin{array}{c}-0.428 \\
(0.284)\end{array}$ & & & \\
\hline Pension $(7+)$ & & & & $\begin{array}{c}0.176 \\
(0.207)\end{array}$ & $\begin{array}{l}0.0919 \\
(0.264)\end{array}$ & $\begin{array}{c}0.00866 \\
(0.306)\end{array}$ & & & \\
\hline Pens.(7+)*E. Europe & & & & & $\begin{array}{c}0.235 \\
(0.396)\end{array}$ & & & & \\
\hline Pens.(0-2)*Low Gov. bond & & & & & $\begin{array}{c}-1.656 \\
(2.817)\end{array}$ & $\begin{array}{c}0.276 \\
(0.287)\end{array}$ & & & \\
\hline Pens.(3-6)*Low Gov. bond & & & & & & $\begin{array}{c}0.264 \\
(0.312)\end{array}$ & & & \\
\hline Pens.(7+)*Low Gov. bond & & & & & & $\begin{array}{c}0.318 \\
(0.365)\end{array}$ & & & \\
\hline Per capita GDP & $\begin{array}{c}11.44 * * * \\
(2.113)\end{array}$ & $\begin{array}{c}10.82 * * * \\
(2.184)\end{array}$ & $\begin{array}{c}11.49 * * * \\
(2.139)\end{array}$ & $\begin{array}{c}11.58 * * * \\
(2.188)\end{array}$ & $\begin{array}{c}11.29 * * * \\
(2.208)\end{array}$ & $\begin{array}{c}11.71 * * * \\
(2.230)\end{array}$ & $\begin{array}{c}2.831^{* * *} \\
(1.009)\end{array}$ & $\begin{array}{c}2.966 * * * \\
(1.044)\end{array}$ & $\begin{array}{c}2.902 * * * \\
(1.027)\end{array}$ \\
\hline Credit to private sector & $\begin{array}{c}0.0172 \\
(0.0439)\end{array}$ & $\begin{array}{c}0.0133 \\
(0.0388)\end{array}$ & $\begin{array}{c}0.0115 \\
(0.0446)\end{array}$ & $\begin{array}{l}0.00901 \\
(0.0445)\end{array}$ & $\begin{array}{l}0.00377 \\
(0.0413)\end{array}$ & $\begin{array}{l}0.00189 \\
(0.0476)\end{array}$ & $\begin{array}{c}-0.0169 * \\
(0.00877)\end{array}$ & $\begin{array}{c}-0.0171^{*} \\
(0.00878)\end{array}$ & $\begin{array}{c}-0.0177 * \\
(0.00904)\end{array}$ \\
\hline Terms of trade & $\begin{array}{c}0.153 * * * \\
(0.0527)\end{array}$ & $\begin{array}{c}0.156 * * * \\
(0.0544)\end{array}$ & $\begin{array}{c}0.148 * * * \\
(0.0543)\end{array}$ & $\begin{array}{c}0.142 * * * \\
(0.0518)\end{array}$ & $\begin{array}{c}0.146 * * * \\
(0.0531)\end{array}$ & $\begin{array}{c}0.141 * * * \\
(0.0498)\end{array}$ & $\begin{array}{c}0.0635 * * * \\
(0.0231)\end{array}$ & $\begin{array}{c}0.0637 * * * \\
(0.0231)\end{array}$ & $\begin{array}{c}0.0636 * * * \\
(0.0231)\end{array}$ \\
\hline
\end{tabular}




\begin{tabular}{l|ccccccccc} 
Unemployment rate & -0.220 & -0.211 & -0.228 & -0.202 & -0.192 & -0.222 & $0.124^{* * *}$ & $0.122 * * *$ & $0.121^{* * *}$ \\
& $(0.146)$ & $(0.155)$ & $(0.143)$ & $(0.145)$ & $(0.150)$ & $(0.138)$ & $(0.0453)$ & $(0.0454)$ & $(0.0460)$ \\
Observations & 700 & 700 & 700 & 700 & 700 & 700 & 686 & 686 & 686 \\
Cross sections & 36 & 36 & 36 & 36 & 36 & 36 & 36 & 36 \\
R2 & 0.464 & 0.472 & 0.482 & 0.474 & 0.477 & 0.495 & & \\
Adjusted R2 & 0.458 & 0.464 & 0.474 & 0.467 & 0.466 & 0.484 & & No/Yes & No/Yes \\
Time/Country FE & No/No & No/No & No/No & No/No & No/No & No/No & Nos \\
\hline \hline
\end{tabular}

Notes: The dependent variable in columns (1-6) is the share of gross domestic savings in GDP. The dependent variable in columns (7-

9 ) is the change in the share of gross domestic savings in GDP. Columns (1-3) report estimates from static regressions without fixed effects. Columns (4-6) report estimates from model with time-varying effects. Columns (7-9) report estimates from dynamic model The numbers in parentheses are robust clustered standard errors (1-6) and bootstrap standard errors (7-9).*, ** and *** denote significance at $10 \%, 5 \%$ and $1 \%$. All covariates are as in the main text. 